\title{
Earnings Management, Benchmarks, and Market Valuation - A Perspective from the Hospitality Industry
}

\author{
Fanghong Jiao \\ Bradley University \\ Lucy Wenxiang Lu \\ Bradley University
}

Hospitality industry (hotels and restaurants) has developed into an important sector in the world economy. We hypothesize and test that hospitality managers behave differently in managing reported earnings to meet/marginally exceed earnings benchmarks. We find that hospitality managers do not apply as much gain on asset sales and/or discretionary accruals as managers in the other industries, but they tend to promote sales by offering deep discounts/lenient credit terms and reduce discretionary expenses to meet/ marginally exceed earnings benchmarks. The market rewards them with a significant premium. The results of this study have important implications for hospitality managers, practitioners, and regulators.

\section{INTRODUCTION}

Accounting literature documents that managers manipulate earnings by changing accounting policies (Healy, 1985), taking real economic actions (Roychowdhury, 2006), and guiding market expectations (Matsumoto, 2002). Managers manage earnings for different incentives (Healy and Wahlen, 1999), and benchmarking (Graham, Harvey, and Rajgopal, 2005) is on the list.

Benchmark is something that serves as a standard by which others may be measured or judged, or a point of reference from which measurements may be made, according to the Merriam-Webster dictionary. Corporate managers benchmark themselves against different standards. Accounting literature documents that managers prioritize as benchmarks positive earnings, beating last period's earnings, and analyst forecast (Burgstahler and Dichev, 1997; Degeorge, Patel, and Zeckhauser, 1999; Graham et al. 2005; Brown and Caylor, 2005). Benchmarking can be achieved through earnings management. Existing literature suggests several measures of real earnings management (REM) and accruals earnings management (AEM) (Gunny, 2010; Roychowdhury, 2006; Jones, 1991; Kothari, Leone, and Wasley, 2005).

Existing literature documents mixed results about the effect of using earnings management to achieve benchmarks on firms' performance and market valuation (Gunny, 2005, 2010; Bhojraj, Hribar, Picconi, and McInnis, 2009). While majority of accounting research documents a negative effect on firms' financial performance, some studies show a positive signaling effect. In the meantime, while most studies 
take a general approach to all industries (except financial institutions and utilities firms), there are only a few studies conducted on specific industries. Different industries appear different characteristics. For example, hospitality industry has different labor structure and regulation requirements than others. Therefore, a study on a specific industry can contribute to the existing accounting literature.

Hospitality industry has evolved into a major portion of the world economy. For example, a report traced from http://hospitalitynet.org/post.html?news shows that hotels are only a small portion of the hospitality industry. However, global revenues from hotels are expected to generate a revenue of US\$550 billion in 2016, a jump of $\$ 100$ billion from the 2011 figure.

Characteristics related to service warrant an empirical study on this ever-expanding hospitality industry. Certain characteristics related to the hospitality industry may determine some special features that managers in this industry demonstrate in their benchmarking behavior. First of all, hospitality industry is labor intensive (Law, Leung, and Cheung, 2012; Song, Chon, Ding, and Gu, 2015); Secondly, its product is perishable in nature (Yoo, Lee, and Bai, 2011); Finally, the service nature of its product may dictate certain nuances in revenue recognition different from those related to tangible products of the other industries. Therefore, we predict that managers in the hospitality industry exhibit different benchmarking behaviors from those in the other industries. To be specific, we examine hotels and restaurants - two represented areas in the hospitality industry.

This study first examines whether managers of hospitality firms differ from those of other industries in engaging earnings management for benchmarking purposes. Managers in general are suspects of earnings management if their benchmarking behavior exhibits a pattern. Prior literature identifies incidences of earnings management as those avoiding zero earnings and negative earnings increase. We use this documented technique to identify our SUSPECT firms.

Results from the initial step suggest some differences in hospitality managers' benchmarking behavior. In general, RESTAURANT dominates HOTEL in our sample in determining the combined effects of earnings management. Specifically, the results indicate that RESTAURANT firms offer deeper discounts/more lenient credit sales and/or cut discretionary expenses to meet/marginally exceed zero earnings/growth. The results also suggest that SUSPECT*HOTELs do use income increasing discretionary accruals to meet/marginally exceed zero earnings/growth, whereas SUSPECT*RESTAURANTs do not use as much income-increasing discretionary accruals as firms in other industries.

Given the evidence that hospitality managers apply certain earnings management techniques in benchmarking, this study next presents how the equity market values these firms' benchmarking behavior. Tobin's Q $(T Q)$ is documented as a justifiable measure of firms' market valuation (Anderson and Reeb, 2003). We use $T Q$ to test market valuation of hospitality firms that apply those identified earnings management techniques for benchmarking purposes.

The valuation results suggest that if managers from hospitality firms apply earnings management for benchmarking purposes, the market assigns a premium to these firm, supporting the signaling effect documented by prior studies. Specifically, if HOTEL managers for benchmarking purposes resort to discounted sales to boost earnings, cutting discretionary expenses, timing asset sales to gain on asset sales, and increasing discretionary accruals, their firms fare much better.

The structure of this paper is as follows. The next section discusses the hypotheses development, followed by research methodology, data, and discussion of empirical results. The last section concludes.

\section{HYPOTHESES DEVELOPMENT}

Majority of earnings management literature applies to all but such industries as utilities and financial institutions. There are a few studies focused on specific industries. For instance, Pincus and Rajgopal (2002) find that oil and gas-producing firms use abnormal accruals and hedge with derivatives as substitutes to manage earnings volatility. Eldenburg, Gunny, Hee, and Soderstrom (2011) find evidence that certain California nonprofit hospitals reduce noncore business expenditures to boost earnings. However, to the best of our knowledge, no existing research has explored the hospitality industry in its 
applications of earnings management to meet/marginally exceed earnings benchmarks. Characteristics and the increasing importance of this industry warrant some empirical research with regard to this question.

The hospitality industry is the largest industry and one with unique features (Hesford and Potter, 2010). Hesford and Potter (2010) also state that accounting research on this industry "can contribute both to accounting practice and to the broader academic literature in accounting." Law, Leung, and Cheung (2012) suggest that there is no clear consensus as to what the hospitality industry actually covers. Although the most research attention regarding the hospitality industry is focused on hotels, restaurants also attract significant attention as the second most researched area. Therefore, in our study, the hospitality industry covers both hotels and restaurants.

The hotel sector in the hospitality industry has experienced unprecedented growth in the world economy. The growth in developing countries is exceptionally fast. Chen and Kim (2010) note that in China, the number of hotels before the open policy of 1979 was only 100. By 2002, there were more than 10,000 star-rated hotels. The World Economic Forum (2018) forecasts that by 2030, China will be the world's number-one tourism destination, with approximately 130 million arrivals each year by the end of the next decade.

Characteristics related to service warrant an empirical study on this ever-expanding hospitality industry. The accounting literature (Roychowdhury, 2006) documents that cash flow from operations $(C F O)$ is a linear function of sales. However, the characteristics of the hospitality industry's product determine that hospitality managers' capacity in managing earnings through $C F O$ will be constrained to some extent.

On the one hand, the product of the hospitality industry is service, and it is perishable in nature (Yoo et al., 2011). For a hotel, revenue is generated when a room is sold (booked and used by a guest). However, if the room is not sold, the revenue for this room is never realized. The same logic applies to a restaurant dining table. If there are no guests patronizing a restaurant and occupying a table, the possible revenue from it is also forfeited.

On the other hand, constrained capacity in providing service renders its perishable nature even more fragile. The inventories of rooms in a hotel and dining tables in a restaurant are very different from those of other tangible products because only a limited inventory is available for sale, and the inventory remains after the sale. For a manufacturing enterprise, products such as television sets and packaged foods can be sold another time when demand is higher. However, for a hotel with a fixed number of 500 rooms, no matter what demand is, there are only 500 rooms for sale. If there is demand for 300 rooms, the revenue of the remaining 200 rooms will be forfeited forever; conversely, hotels cannot add 200 rooms to their 500 -room capacity when the demand is for 700 rooms.

However, the seasonal nature of the hospitality business also provides managers with opportunities to manage earnings through $C F O$ despite the fact that inventory is constrained. Jolliffe and Farnsworth (2003) suggest that embracing seasonality rather than challenging it differentiates a hospitality firm from the rest, resulting in better performance. During slow seasons, managers can boost sales by offering deep discounts or lenient credit terms to fill empty rooms or tables. Different from hotels, restaurants have the capability and flexibility to boost sales by offering catering services outside the properties regardless of slow or busy seasons. Our first hypothesis is derived from reasoning above.

Hypothesis 1a. Hospitality managers are constrained in their capacities to use as much CFO as managers from other industries. However, RESTAURANT managers that meet/marginally exceed zero earnings/growth tend to apply this earnings management practice.

Hospitality industry, especially the RESTAURANTs, is labor intensive (Law et al., 2012; Song et al., 2015), its employment turnover rate is high (Kusluvan, Kusluvan, Ilhan, and Byuruk, 2010), and its labor costs are high (Schmenner, 1986), which imply that RESTAURANTs must invest more in employee training and career development than any other industry to maintain a workforce of good quality to stay competitive. Some argue that hospitality managers may implement effective and efficient human 
resource (HR) management policies to reduce discretionary expenses. For instance, Kusluvan et al. (2010) point it out that hospitality firms can effectively manage a pool of temporary workers to reduce labor costs. Our second hypothesis is derived from the above argument.

Hypothesis 1b. Labor-intensiveness, high employment turnover and labor costs of the hospitality industry may dictate that RESTAURANT managers that meet/marginally exceed zero earnings/growth tend to cut discretionary expenses to achieve this goal.

Hospitality managers may strategically time asset sales to manage earnings. Juarez (2014) states that fixed "assets such as PP\&E are essentials to the hospitality industry." Hotel rooms and restaurant tables are special in that they are both inventory items and fixed assets. They remain with the fixed assets property after service has been provided. Hotels generally have more fixed assets than restaurants. Considering the size of hotels, rooms claim a much larger portion of fixed assets than other types of fixed assets such as elevators or electric generators. However, hotel buildings are not usual items to buy and sell except in business acquisitions and mergers. Restaurants, on the other hand, have more moveable fixed assets for managers to strategically sell for a gain. However, the relative portion of this type of fixed assets is still much less than that from other industries, such as a manufacturing business. Our third hypothesis is derived from reasoning above.

Hypothesis 1c. The scarcity of salable fixed assets of the hospitality industry dictates that hospitality managers that meet/marginally beat zero earnings/growth may not use as much gain on asset sales as that used by managers from other industries.

Hospitality managers may manage discretionary accruals accounts to meet/marginally exceed earnings benchmarks. Hotels are intensive in depreciable fixed assets, and depreciation expense claims a significant non-cash portion in reconciling gross income with the bottom line. However, the relative scarcity of depreciable fixed assets of restaurants may dictate that restaurant managers do not manage discretionary accruals as much as managers from other industries.

The service nature of their products may also contribute to hospitality managers' inability to use discretionary accruals to meet/marginally beat earnings benchmarks. Revenues are "earned." For a manufacturing firm, revenues are earned when its products are delivered. However, in contrast, for a hotel and restaurant, revenues are not earned usually until the service is provided and consumed, leaving hospitality managers much less flexibility in manipulating accruals arising from accounts receivables. Our fourth hypothesis is derived from the above argument.

Hypothesis 1d. Concentration in fixed assets of HOTELs but not RESTAURANTs may dictate that HOTEL managers meeting/marginally beating zero earnings/growth tend to use discretionary accruals to manage earnings.

The equity market rewards firms that meet/exceed earnings benchmarks even though they are suspected of achieving this goal through earnings management (Bartov, Givoly, and Hayn, 2002). Meeting/marginally exceeding benchmarks is evidence of smooth earnings (Brown, 2001). Givoly and Ronen (1981) imply that firms' smooth earnings are signals to the market to improve investors' perception of firm risks, to increase the persistence of earnings, and to notify investors of firms' future growth. Trueman and Titman (1988) suggest that managers smooth earnings to provide claim holders with the perception of a stable firm, hence to have a positive effect on firms' market valuation. Therefore, our hypothesis for market valuation is stated as follows:

Hypothesis 2. Hospitality managers' applications of earnings management to meet/marginally exceed zero earnings/growth are positively associated with the market valuation of this industry. 


\section{METHODOLOGY}

\section{REM and $A E M$ Estimations}

Accounting literature documents REM and $A E M$ measures. For example, Roychowdhury (2006) finds that managers can manage earnings by boosting sales. In doing so, they offer deep price discounts and lenient credit sales. For a limited period of time, this strategy may bolster the sales volume, assuming that the suppliers also offer similar terms to the firm. However, when prices are resumed at the normal higher level, consumers may not continue their patronage as before. In the long run, the cash flow from operations $(C F O)$ will suffer. Specifically, the $C F O$ will be abnormally lower for this entity than that of any other entity in the same industry year.

Following Roychowdhury (2006), we use the following model to estimate the abnormal level of REM in terms of $C F O$.

$$
C F O_{t} / A_{t-1}=\alpha_{0}+\alpha_{1}\left(1 / A_{t-1}\right)+\alpha_{2}\left(S_{t} / A_{t-1}\right)+\alpha_{3}\left(\Delta S_{t} / A_{t-1}\right)+\varepsilon_{t}
$$

where :

$$
\begin{array}{ll}
C F O_{t} & =\text { cash flow from operations at year t (data \#308); } \\
A_{t-1} & =\text { total assets at the beginning of the year (data \#6); } \\
S_{t} & =\text { total sales at year } \mathrm{t}(\text { data } \# 12) ; \\
\Delta S_{t} & =\text { change in sales at year t. }
\end{array}
$$

In this equation, scaled (by assets at the beginning of the year) $C F O$ is a linear function of scaled sales and change in sales. We estimate this equation using observations from the same industry and year. The residual from each observation will be the abnormal level of $C F O$ compared to the same industryyear average. Since a lower value of residuals represents a higher level of $R E M$ using $C F O$, we adjust the value of residuals by multiplying (-1) to arrive at the magnitude of REM using CFO (REM_CFO). Therefore, the higher the value of REM_CFO, the higher the magnitude of $R E M$ in this respect.

According to Roychowdhury (2006), managers may use their discretion to cut expenses on advertising, R\&D, and SG\&A (the sum of these is DISEXP). DISEXP is expressed as a linear function of scaled sales from the prior period to avoid any confusion from the current year impact. If managers resort to this REM approach to increase reported earnings, then the current year DISEXP for the entity will be lower than the industry-year average. Therefore, we adjust the residuals by multiplying $(-1)$ to arrive at the magnitude of REM_DISEXP. The higher the value of REM_DISEXP, the higher the magnitude of $R E M$ in this respect.

$\operatorname{DISEXP} t / A_{t-1}=\beta_{0}+\beta_{1}\left(1 / A_{t-1}\right)+\beta_{2}\left(S_{t-1} / A_{t-1}\right)+\varepsilon_{t}$

where:

DISEXP $\quad=$ the discretionary expense at year $\mathrm{t}$, the sum of advertising expense (data \#45), research and development expense (data \#46), and selling and general administrative expense (data \#189). Following Roychowdhry (2006), as long as SG\&A is available, advertising expenses and $R \& D$ expenses, if missing, are set to zero.

$S_{t-1} \quad=$ net sales at year t 1 ;

Strategically timing asset sales is one of the REM methods (Bartov, 1993) through which managers use the gain/loss on asset sales to smooth earnings and use the gain on asset sales $(G O A S)$ to avoid violating debt covenants with regards to the debt/equity ratio. Bartov (1993) finds that using GOAS is management's preferred approach to boosting earnings versus early retirement of long-term debts; notably, the current acquisition cost method allows GOAS to be included in the income from continuing operations, compared to the gain on early retirement of long-term debt that is categorized in the 
extraordinary item section of the income statement. He adds that managers prefer this accounting treatment because analysts pay more attention to the results from the continuing operations than to the bottom line, and the ultimate goal is to use this strategy to manipulate market reactions. In addition, he reasons that managers prefer this approach because they have complete discretion in this accounting treatment.

Asset sales include selling items such as $P P \& E$, and long-term investments. According to Gunny (2010), GOAS is a linear function of market value, $T Q$, internal funds available, the volume of asset sales, and investment sales. We estimate this equation based on industry-year observations to obtain the residual for each observation as the magnitude of REM in this respect (REM_GOAS).

$$
\begin{aligned}
G O A S_{t} / A_{t-1}= & \gamma_{0}+\gamma_{1}\left(1 / A_{t-1}\right)+\gamma_{2} M_{K T V_{t}}+\gamma_{3} T Q_{t}+\gamma_{4}\left(\text { IntFnd }_{t} / A_{t-1}\right) \\
& +\gamma_{5}\left(\text { ASale }_{t} / A_{t-1}\right)+\gamma_{6}\left(\text { InvSale }_{t} / A_{t-1}\right)+\varepsilon_{t}
\end{aligned}
$$

where

$$
\begin{array}{ll}
\text { GOAS }_{t} & =\text { gain/loss on asset sales [Data } 213 *(-1) \text { to make the interpretation } \\
& \text { straightforward since the gain is coded negative in Compustat] in year } \mathrm{t} ; \\
\text { MKTV } & =\text { market value of asset (natural log) in year } \mathrm{t} ; \\
T Q_{t} & =\text { Tobin's } \mathrm{Q} \text { in year } \mathrm{t} ; \\
\text { IntFnd }_{t} & =\text { internal funds in year } \mathrm{t} ; \\
\text { ASale }_{t} & =\text { asset sales (long-lived assets) in year } \mathrm{t} \text {, and } \\
\text { InvSale }_{t} & =\text { investment sales (long-lived) in year } \mathrm{t} .
\end{array}
$$

According to Jones (1991), total accruals are a linear function of change in sales and $P P \& E$, because the majority of accruals are due to the existence of accounts receivable and depreciation, the non-cash portion in arriving at the net income. We estimate the residuals (the discretionary accruals $(D A)$ ) from the following equation to represent the magnitude of $A E M$. The higher the $D A$, the higher the magnitude a firm applies $A E M$. We follow Jones (1991):

$T A_{t} / A_{t-1}=\delta_{0}+\delta_{1}\left(1 / A_{t-1}\right)+\delta_{2}\left(\Delta S_{t} / A_{t-1}\right)+\delta_{3}\left(P P E_{t} / A_{t-1}\right)+\varepsilon_{t}$

where

$$
\begin{array}{ll}
T A_{t} & =\text { total accruals at year } \mathrm{t}, \text { calculated as the difference between income before the } \\
& \text { extraordinary items (data } \# 18) \text { and CFO (data \#308); } \\
\Delta S_{t} & =\text { change in sales at year } \mathrm{t}(\text { data } \# 12) ; \\
P P E_{t} & =\text { gross property, plant, and equipment at year } \mathrm{t} \text { (data } \# 7) ;
\end{array}
$$

We use Fama-MacBeth regressions to estimate the coefficients of equations (1) through (4). Following Roychowdhury (2006), Gunny (2010), and Jones (1991), we estimate equations (1) through (4) using observations of the same industry and year. We also require at least 15 observations for each industry-year group. Since we have already adjusted the sign on some of the residuals from the equations, the higher the value, the greater the magnitude of applying REM and AEM.

\section{Selection Bias Issue}

The next step is to identify firms that are suspected of using earnings management to meet/marginally exceed earnings benchmarks. Following Gunny (2010), we identify SUSPECT firms as those that meet/marginally beat zero earnings/growth. Meeting/marginally beating zero earnings is defined as the ratio that is greater than or equal to zero but less than or equal to 0.01 between income before extraordinary items and total assets at the beginning of the year; meeting/marginally beating zero earnings growth is defined as the ratio that is greater than or equal to zero but less than or equal to 0.01 between 
the change in income before extraordinary items over prior year and total assets at the beginning of the year.

Firms may self-select to meet/marginally beat zero earnings/growth. Without addressing this selfselection issue, further analyses related to SUSPECT may suffer from the omitted variable (i.e., SUSPECT is endogenous) problem (Wooldridge, 2009, p. 253). Following Heckman (1979) Two-Step procedure, we first model that SUSPECT is a linear function of variables that prior literature documents related to firms' incentives to meet/marginally beat zero earnings/growth. We run a selection model on all sample firms to obtain the inverse Mills ratio (IMR). IMR is added as a control variable in the regression to test whether SUSPECT HOTEL firms and SUSPECT RESTAURANT firms apply more REM and/or AEM, and in the valuation model to test whether the equity market rewards SUSPECTs in HOTEL and RESTAURANT firms' managerial behavior of using $R E M$ and/or $A E M$ to meet/marginally beat zero earnings/growth. We use the following probit model to explain firms that meet/marginally beat zero earnings/growth:

$$
\begin{gathered}
\operatorname{Prob}\left[\operatorname{SUSPECT}_{t}=1\right]=\text { Probit }\left(\theta_{0}+\theta_{1} \operatorname{SHARES}_{t}+\theta_{2} \text { ROA }_{t-1}+\theta_{3} L E V_{t-1}\right. \\
\left.+\operatorname{SIC}+Y E A R+\varepsilon_{t}\right)
\end{gathered}
$$

where

SUSPECT = an indicator variable that is equal to one if either of the following two variables is greater than or equal to zero but less than or equal to 0.01 : (1) zero earnings, defined as net income from operations divided by the beginning balance of total assets; (2) earnings growth, defined as the difference of net income from operations between the current year and the prior year, divided by the beginning balanctotal assets;
SHARES
= natural log of shares outstanding;
$R O A$
$=$ return on assets, calculated as income before extraordinary items over total assets at the beginning of the year;
$L E V \quad=$ leverage, calculated as the ratio of total long-term debt to total assets at the beginning of the year;
SIC $\quad=$ Standard Industrial Classification.

The dependent variable is $S U S P E C T_{t}$, a dichotomous variable that is equal to one if a firm meets/marginally beats zero earnings/growth. Selection of the independent variables in this model is based on prior literature that suggests firms' incentives to meet/beat earnings benchmarks. The magnitude of meeting/beating earnings benchmarks is proportional to the number of SHARES outstanding (Zang, 2012). We, therefore, add SHARES (log number of shares outstanding) to control for the magnitude of meeting/beating earnings benchmarks, and we predict this coefficient estimate to be positive. Return on assets $(R O A)$, calculated as the ratio between income before extraordinary items and total assets at the beginning of the year is added to control for firms' accounting performance (Zang, 2012). Firms with good accounting performance are more likely to meet/beat earnings benchmarks. Therefore, we predict this coefficient estimate to be positive. Jiang (2008) examines the effects of meeting/beating earnings benchmarks on the cost of debt. He finds that meeting/beating earnings benchmarks is associated with lower cost of debt, and meeting/beating zero earnings enjoys the most premium in terms of change in credit ratings upgrade and change in initial bond yield. Therefore, we add leverage (LEV) as a control variable for the debt market, calculated as the ratio between the long-term debt and total assets at the beginning of the year. Since the debt market puts more weight on meeting/beating zero earnings benchmark, we predict that firms with more leverage are likely to meet/beat zero earnings benchmark. Therefore, we predict that the coefficient estimate of $L E V$ is positive. SIC and YEAR dichotomous variables are added to control for differences in industries and years. 


\section{Extent of Hospitality Industry Using Earnings Management to Meet/Marginally Beat Zero Earnings/Growth}

Following Gunny (2010), we use the following equation to test the extent to which HOTEL and RESTAURANT SUSPECT firms use earnings management to meet/marginally exceed zero earnings/growth.

$$
\begin{aligned}
\text { DEM }_{t} / D D A_{t}=\eta_{0}+\eta_{1} \text { SUSPECT }_{t}+\eta_{2} \text { HOTEL }_{t}+\eta_{3} \text { RESTAURANT }_{t} \\
+\eta_{4} \text { SUSPECT }_{t} * \text { HOTEL }_{t}+\eta_{5} \text { SUSPECT }_{t} * \text { RESTAURANT }_{t} \\
+\eta_{6} \text { SIZE }_{t}+\eta_{7} \text { MTB }_{t}+\eta_{8} \text { ROA }_{t}+\eta_{9} I M R
\end{aligned}
$$

where

$$
\begin{aligned}
& D E M_{t} / D D A_{t} \quad=\text { a dummy variable (sign-adjusted accrual } D A \text { and } R E M \text { measures, } \\
& \text { identified in equations (1) through (4)) that is equal to one if it is greater } \\
& \text { than or equal to zero but less than or equal to } 0.01 \text {; otherwise, it is equal to zero; } \\
& \text { HOTEL = an indicator variable that is equal to one if its two-digit SIC code is 70; } \\
& \text { otherwise, it is equal to zero; } \\
& \text { RESTAURANT = an indicator variable that is equal to one if its two-digit SIC code is 58; } \\
& \text { otherwise, it is equal to zero; } \\
& \text { SIZE = natural log of total assets at current year; } \\
& \text { MTB = market to book ratio, calculated as the ratio market value to the book } \\
& \text { value of common equity; } \\
& \text { IMR = inverse Mills ratio obtained from Heckman (1979) first step procedure. }
\end{aligned}
$$

The variables of interest are the two interaction terms, SUSPECT $T_{t} * H O T E L_{t}$ and SUSPECT $T_{t}$ * RESTAURANT, and the predicted signs for them are described in the hypothesis development section. Predicted signs of other variables are stated as follows. SUSPECT is expected to be statistically significant, either positive or negative, except for when DREM_GOAS is the dependent variable (Gunny, 2010; Roychowdhury, 2006). We have no predicted signs for $\bar{H} O T E L$ and RESTARANT. Variables such as SIZE, MTB, and ROA are added to control firm specific characteristics. IMR is added to control for selection bias from the Heckman (1979) first step procedure. If IMR is not statistically significant, it suggests that there is no self-selection bias issue, and if IMR is statistically significant, it suggests the importance of controlling self-selection bias issue (Zang, 2012, p. 699).

\section{Market Valuation}

Following prior literature (Kaplan and Zingales, 1997; Anderson and Reeb, 2003), we use $T Q$ as a market measure of firms' performance. We calculate $T Q$ as the ratio between market value of assets (i.e., book value of assets data + market value of common equity, calculated as the fiscal year-end stock price of common equity multiplied by number of common shares outstanding at the end of year - book value of common equity - balance sheet deferred taxes) and book value of assets.

To examine market valuation, following prior accounting literature (Zang, 2012; Gunny, 2010), we control for the effects of SIZE (log of total assets), growth (market to book ratio $(M T B)$ ), leverage (LEV), and firms' financial health ( $Z$ S SCORE).

We use the following regression to test Hypothesis 2:

$$
\begin{aligned}
T Q_{t}=\theta_{0}+ & \theta_{1} \text { BEAT }_{t}+\theta_{2} \text { JUSTMISS }_{t}+\theta_{3} \text { SUSPECT }_{t}+\theta_{4} \text { HOTEL }_{t} \\
& +\theta_{5} \text { RESTAURANT }_{t}+\theta_{6} \text { DREM }_{t} / D D A_{t} \\
& +\theta_{7-14} \text { SUSPECT }_{t} * \text { HOTEL }_{t} / \text { RESTAURANT }_{t} * \text { DREM }_{t} / D D A_{t} \\
& +\theta_{15} \text { SIZE }_{t}+\theta_{16} \text { MTB }_{t}+\theta_{17} \text { LEV }_{t}+\theta_{18} Z_{-} S C O R E_{t}+\theta_{19} I M R+\varepsilon_{t}
\end{aligned}
$$

where: 
BEAT = a dummy variable that is equal to one if either zero earnings (or earnings growth), is greater than 0.01 ; otherwise it is equal to zero;

JUSTMISS = a dummy variable that is equal to one if either zero earnings (or earnings growth) is less than zero but greater than or equal to -0.01 ; otherwise it is equal to zero;

Z_SCORE = a measure of financial health (Altman, 1968), calculated as:

$3.3 *\left(\mathrm{EBIT}_{\mathrm{t}} / \mathrm{A}_{\mathrm{t}-1}\right)+1.0 *\left(\mathrm{~S}_{\mathrm{t}} / \mathrm{A}_{\mathrm{t}-1}\right)+1.4 *\left(\mathrm{RE}_{\mathrm{t}} / \mathrm{A}_{\mathrm{t}-1}\right)+1.2 *\left(\mathrm{WCAP}_{\mathrm{t}} / \mathrm{A}_{\mathrm{t}-1}\right)$

where

EBIT

$R E$

$=$ earnings before interest and tax expenses;

$W C A P$

$I M R$

$=$ retained earnings; and

= working capital

= inverse Mills ratio obtained from Heckman (1979) first step procedure.

The variables of interest are the interaction terms, and the coefficients of estimates that we are interested in are those of $\theta_{7-14}$. Since we are predicting the signaling effect of earnings management, we are expecting positive coefficient estimates for these terms.

The predictions for the other variables are based on prior literature. According to Bartov et al. (2002), the equity market rewards firms that beat earnings benchmarks, therefore, we are expecting a positive relation between $T Q$ and BEAT. Bhojraj et al. (2009) examine firms that have good earnings quality (negative discretionary accruals) but narrowly miss analysts' forecasts have better long-run performance than those that have bad quality of earnings but beat the benchmark. On the other hand, Skinner and Sloan (2002) find that the market punishes firms that narrowly miss earnings benchmarks. Therefore, we have no particular prediction for the sign of JUSTMISS. Bartov et al. (2002) and Skinner and Sloan (2002) conclude that equity market rewards/punishes firms that meet/marginally beat earnings benchmarks. Therefore, we predict the coefficient estimate of SUSPECT to be positive.

As stated before, we have no predictions for HOTEL and RESTAURANTS. We are expecting the coefficient estimates for $D R E M / D D A$ to be negative, indicating their value-destroying nature (Gunny, 2010). Anderson and Reeb (2003) find negative relations between $T Q, S I Z E$, and $L E V$. Therefore, we are predicting negative signs for SIZE and LEV. Anderson and Reeb (2003) operationaliz growth as the ratio between R\&D and sales also find a positive relation between TQ and growth. Therefore, we predict a positive sign for MTB. Financial health is negatively related to firm performance (Gunny, 2010). Therefore, we predict a negative sign for $Z_{-} S C O R E$.

\section{DATA}

\section{Sample}

To test the hypotheses, we collect data from the following sources. According to Bhojraj et al. (2009), yearly data make more sense than quarterly data in the analysis of earnings management because the majority of accruals adjustments occur in the fourth quarter and quarterly reporting of $R \& D$ and advertising expense is sparse. In addition, since $C F O$ data is not available before 1987, we collect yearly data for the period of 1987-2011 for this study. Yearly financial data are from Compustat-North America.

Following Roychowdhury (2006), we reduce SIC codes to the first two digits. We delete utilities industries (SIC codes between 44 and 50, inclusive) and banks and financial institutions (SIC codes between 60 and 69, inclusive) because their financial statements tend to be very different from those of other industries. After deleting missing values, winsorizing at 1 and 99 percentile on continuous variables and requiring at least 15 observations for each industry-year group, we have 108,132 total firm-year observations covering 1,030 industry-year groups for 25 years. 


\section{EMPIRICAL RESULTS}

\section{Descriptive Statistics}

Frequency distributions of zero earnings/growth for HOTEL, RESTAURANT, and other nonhospitality firms are presented in Figures 1-6. Discontinuities and asymmetries occur in these distributions at zero earnings/growth in all figures. These discontinuities and asymmetries are consistent with earnings management efforts by HOTEL, RESTAURANT, and other non-hospitality firms to achieve positive earnings and earnings growth.

FIGURE 1

FREQUENCY DISTRIBUTION OF ZERO EARNINGS

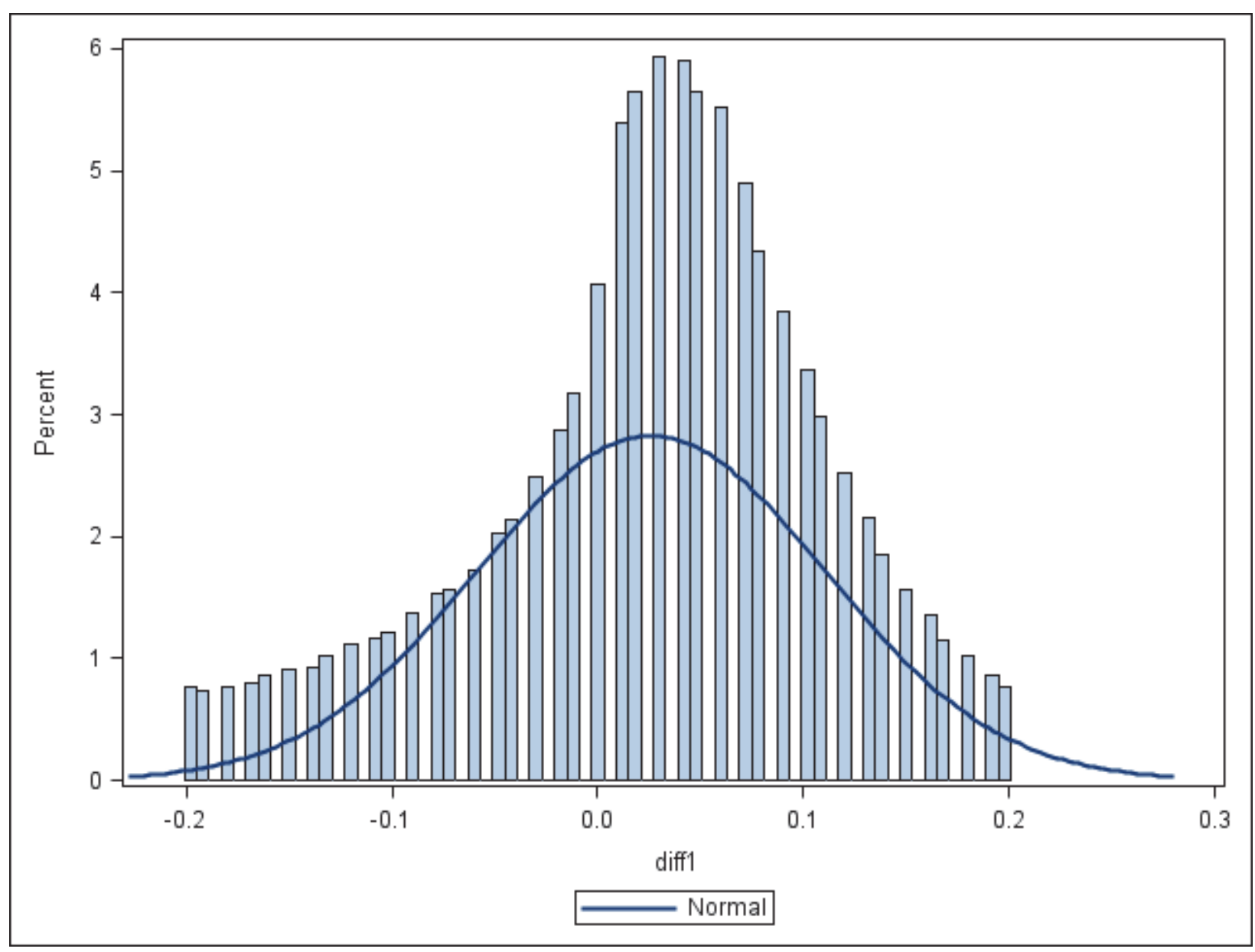

Figure 1. Percentages of firm-year observations for the period of $1987-2011$ for diff1 (zero earnings), measured as income from operations divided by total assets at the beginning of the year. There are 108,132 observations for the entire sample, and 89,496 of them are within the range of greater or equal to -0.20 and less than or equal to 0.20 . 
FIGURE 2

FREQUENCY DISTRIBUTION OF EARNINGS GROWTH

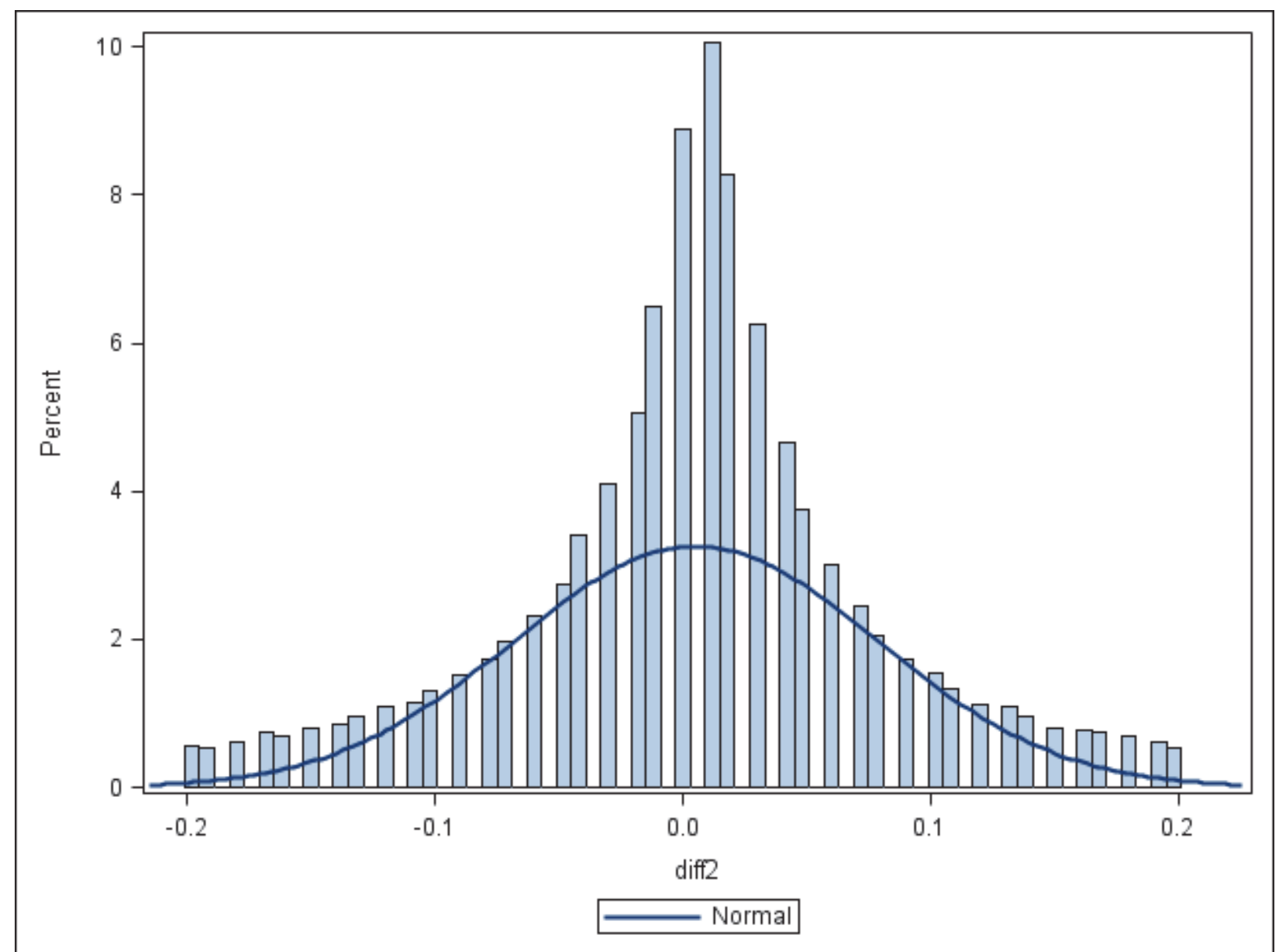

Figure 2. Percentages of firm-year observations for the period of 1987 - 2011 for diff2 (earnings growth), measured as difference between income from operations from current year and that from prior year divided by total assets at the beginning of the year. There are 108,132 observations for the entire sample, and 94,270 of them are within the range of greater or equal to -0.20 and less than or equal to 0.20 . 
FIGURE 3

FREQUENCY DISTRIBUTION OF ZERO EARNINGS (HOTEL)

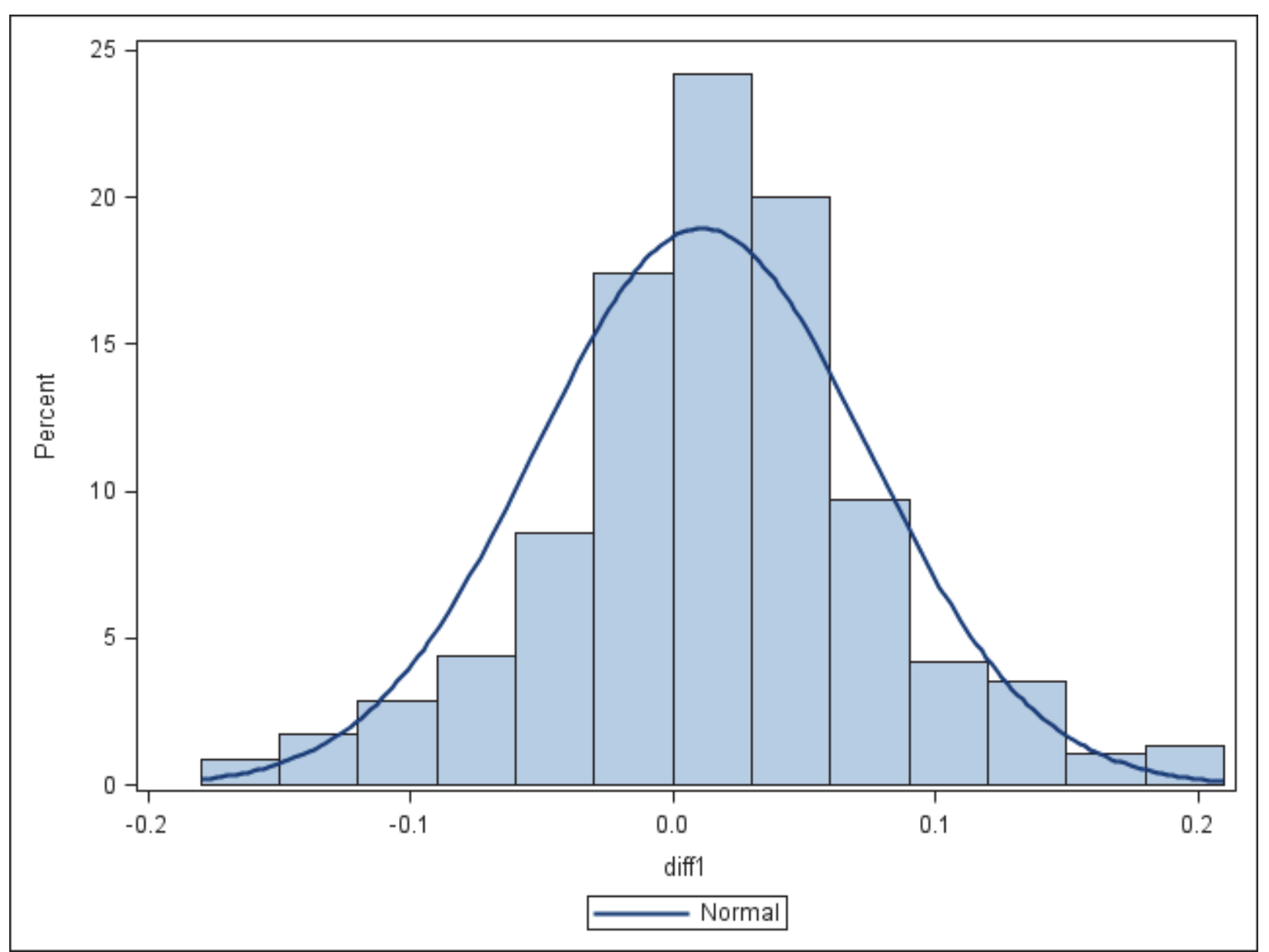

Figure 3. Percentages of firm-year observations for the period of 1987 - 2011 for diff1 (zero earnings) of the Hotel industry (SIC 70), measured as difference between income from operations from current year and that from prior year divided by total assets at the beginning of the year. There are 540 observations for the entire sample, and 454 of them are within the range of greater or equal to -0.20 and less than or equal to 0.20 . 
FIGURE 4

FREQUENCY DISTRIBUTION OF ZERO EARNINGS (RESTAURATN)

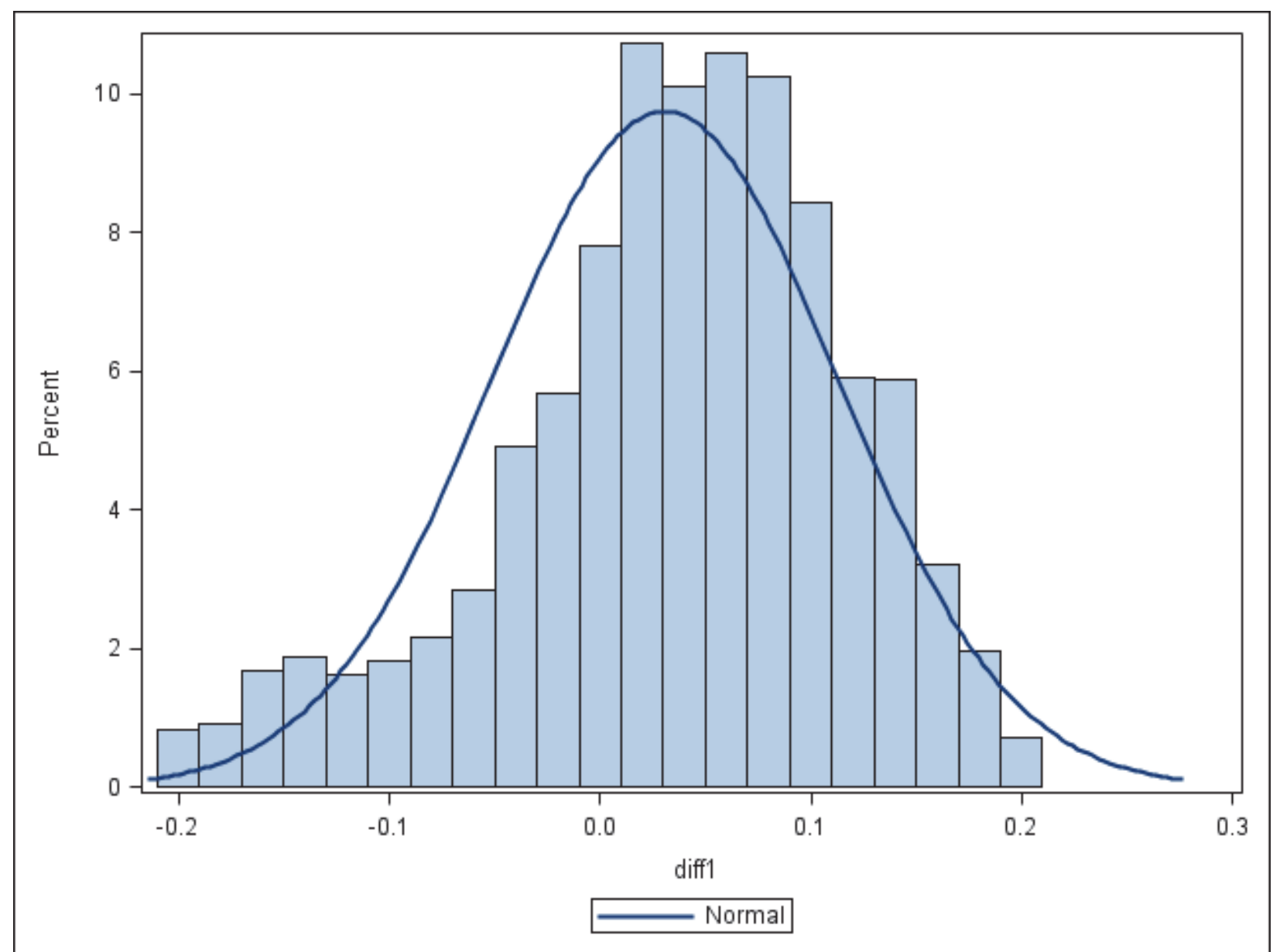

Figure 4. Percentages of firm-year observations for the period of $1987-2011$ for diff1 (zero earnings) of the Restaurant industry (SIC 58), measured as difference between income from operations from current year and that from prior year divided by total assets at the beginning of the year. There are 2,595 observations for the entire sample, and 2,077 of them are within the range of greater or equal to -0.20 and less than or equal to 0.20 . 
FIGURE 5

FREQUENCY DISTRIBUTION OF EARNINGS GROWTH (HOTEL)

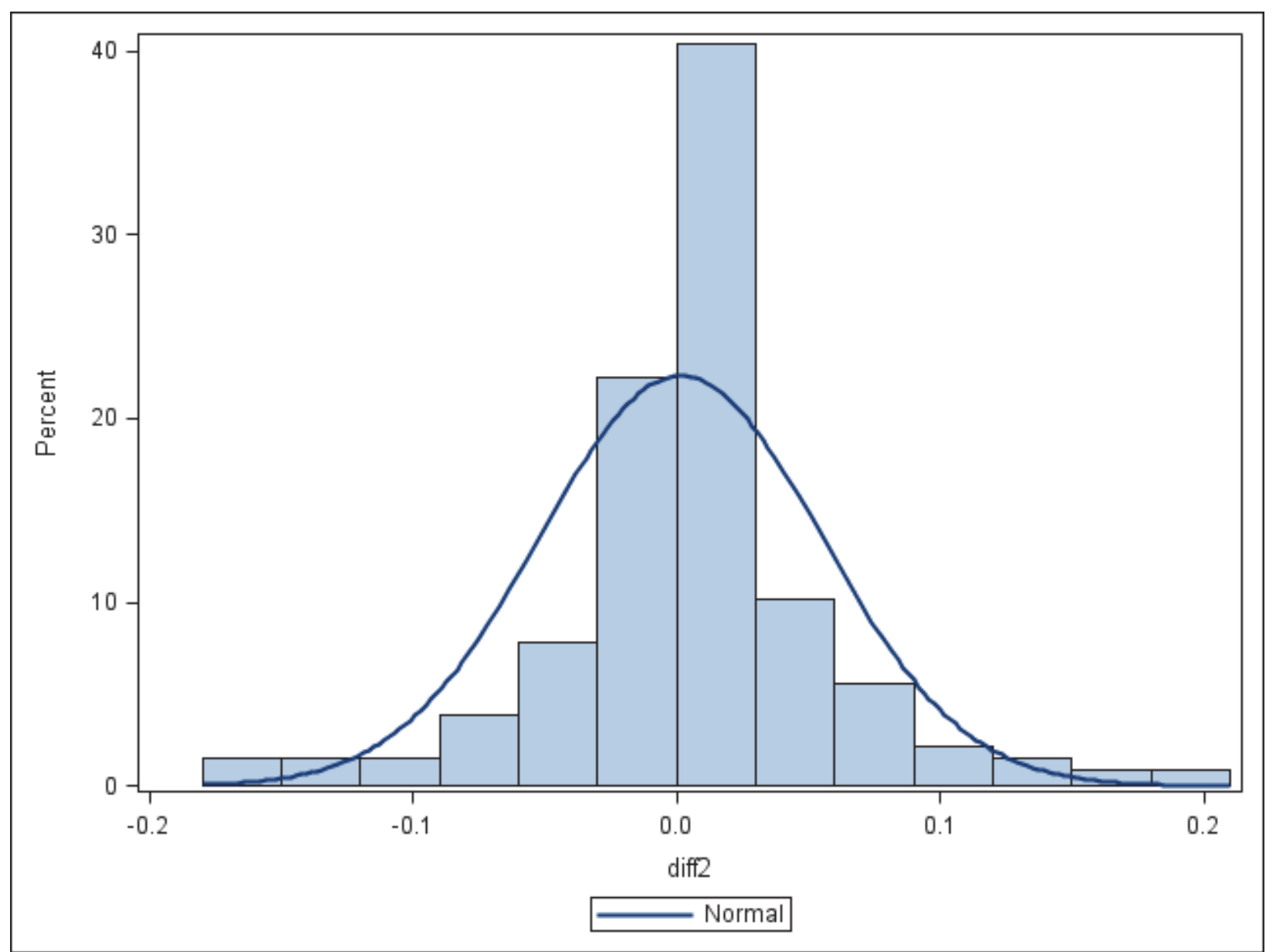

Figure 5. Percentages of firm-year observations for the period of $1987-2011$ for diff2 (earnings growth) of the Hotel industry (SIC 70), measured as difference between income from operations from current year and that from prior year divided by total assets at the beginning of the year. There are 540 observations for the entire sample, and 454 of them are within the range of greater or equal to -0.20 and less than or equal to 0.20 . 


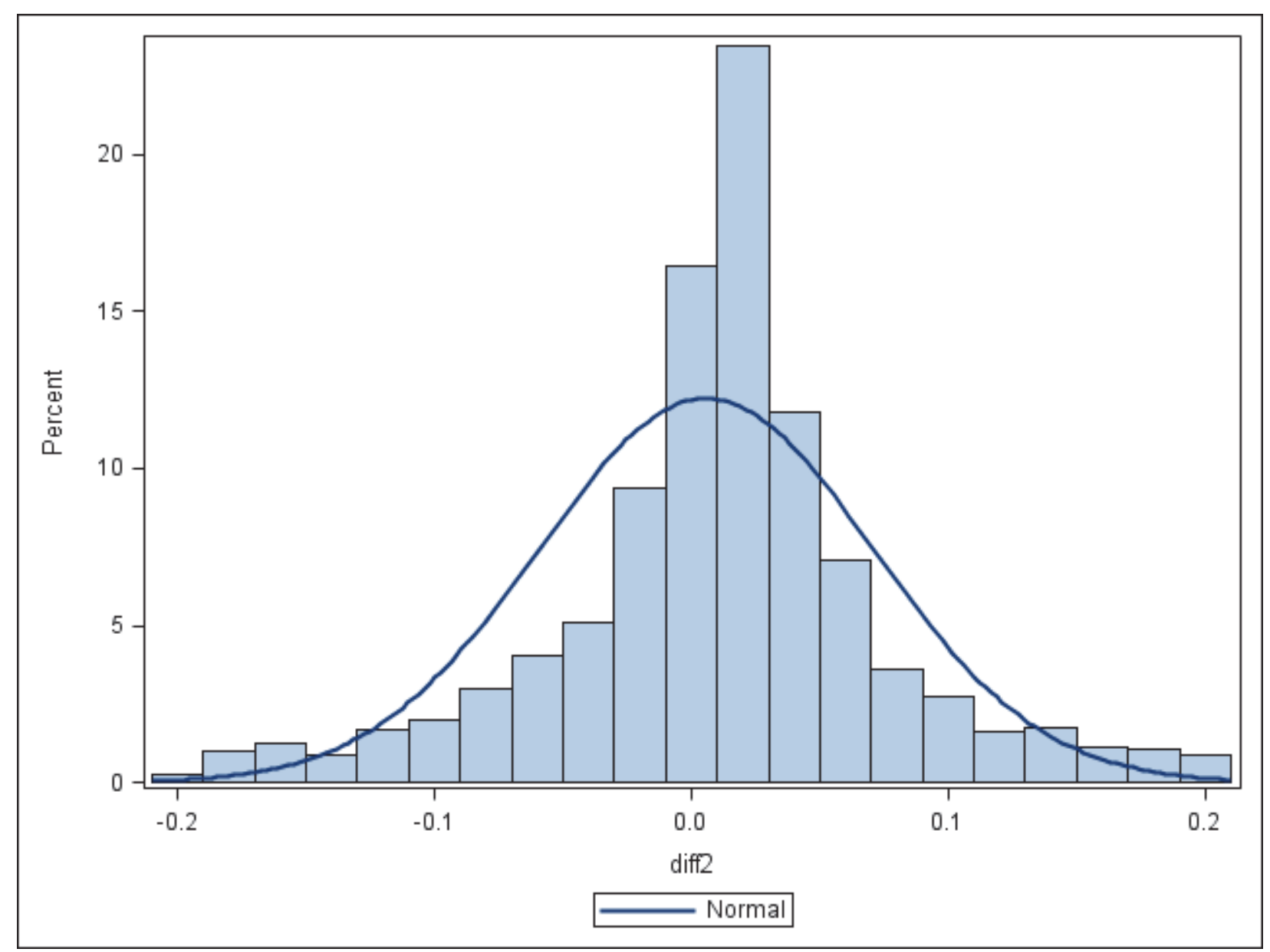

Figure 6. Percentages of firm-year observations for the period of 1987 - 2011 for diff2 (earnings growth) of the Restaurant industry (SIC 58), measured as difference between income from operations from current year and that from prior year divided by total assets at the beginning of the year. There are 2,595 observations for the entire sample, and 2,077 of them are within the range of greater or equal to -0.20 and less than or equal to 0.20 .

Table 1 presents the coefficient estimates of equations (1) through (4) using Fama-MacBeth regressions. The signs and significances of coefficients are generally consistent with those from prior studies, and the consistency ensures the validity of the results derived from these coefficient estimates in further analyses. For instance, the coefficient estimate of deflated $C F O$ on $\Delta S_{t} / A_{t-1}$ is -0.0567 , significant at the 0.05 significance level. The coefficient estimates of deflated DISEXP on all variables have the same signs and significant levels as those from Roychowdhury (2006). 


\section{TABLE 1}

\section{FAMA-MACBETH REGRESSION PARAMETER ESTIMATION}

\begin{tabular}{|c|c|c|c|c|c|c|c|c|}
\hline & $C F O / A_{t-1}$ & & DISEXI & $A_{t-1}$ & $T A / A$ & & $G O A S / A_{t-1}$ & \\
\hline Intercept & -0.0117 & & 0.1972 & $* * *$ & -0.0259 & & -0.0010 & \\
\hline $1 / A_{t-1}$ & -1.0584 & $* * *$ & 2.3329 & $* * *$ & -0.5985 & $* * *$ & 0.0608 & $* * *$ \\
\hline$S_{t} / A_{t-1}$ & 0.0977 & $* * *$ & & & & & & \\
\hline$\Delta S_{t} / A_{t-1}$ & -0.0567 & $* *$ & & & 0.0689 & $* *$ & & \\
\hline \multicolumn{9}{|l|}{$\Delta S_{t-1} / A_{t-1}$} \\
\hline$S_{t-1} / A_{t-1}$ & & & 0.0673 & $* *$ & & & & \\
\hline$P P E_{t} / A_{t-1}$ & & & & & 0.0041 & & & \\
\hline$A S A L E / A_{t-1}$ & & & & & & & 0.2451 & $* * *$ \\
\hline IntFnd/At-1 & & & & & & & 0.0201 & $* * *$ \\
\hline InvSale/ $A_{t-1}$ & & & & & & & 0.0897 & $* *$ \\
\hline$M K T V$ & & & & & & & 0.0001 & \\
\hline$T Q$ & & & & & & & -0.0010 & \\
\hline
\end{tabular}

*/**/*** represent statistical significances at the $10 \% / 5 \% / 1 \%$ levels, two tailed. There are 108,343 firm-year observations, consisting of 1,030 separate industry-year groups over the period of $1987-2011$. The variables are defined as follow:

\begin{tabular}{|c|c|c|}
\hline$A_{t-1}$ & $=$ & the total assets at year $\mathrm{t}-1$ \\
\hline$S_{t}$ & $=$ & net sales at year $\mathrm{t}$ \\
\hline$\Delta S_{t}$ & $=$ & the change in net sales at year $t$ \\
\hline$\Delta S_{t-1}$ & $=$ & change in total sales at year $\mathrm{t}-1$ \\
\hline$P P E_{t}$ & $=$ & the gross property, plant, and equipment at year $\mathrm{t}$ \\
\hline$C F O_{t}$ & $=$ & cash flow from operations at year $\mathrm{t}$ \\
\hline$P R O D_{t}$ & $=$ & the sum of cost of goods sold and the change in inventories at year $t$ \\
\hline$D I S E X P_{t}$ & $=$ & $\begin{array}{l}\text { the discretionary expense, the sum of advertising expense, research and } \\
\text { development expense, and selling and general administrative expense }\end{array}$ \\
\hline$T A_{t}$ & $=$ & $\begin{array}{l}\text { total accruals at year } t \text {, calculated as the difference between income before the } \\
\text { extraordinary items and cash flow from the operating activities }\end{array}$ \\
\hline ASALE & $=$ & long-lived asset sales \\
\hline IntFnd & $=$ & $\begin{array}{l}\text { internal fund, calculated as the sum of income from operations, research and } \\
\text { development expense, and depreciation expense }\end{array}$ \\
\hline InvSale & $=$ & long-lived investment sale \\
\hline$M K T V$ & $=$ & market value \\
\hline$T Q$ & $=$ & $\begin{array}{l}\text { Tobin's Q, calculated as market value of assets divided by book value of assets } \\
\text { Descriptive statistics, industry differences, and correlations among variables relevant to } \\
\text { H1 are presented in Tables 2-4. Results from Heckman first step estimation are presented } \\
\text { in Table 5, and an inferential test of this hypothesis (H1) is presented in Table } 6 \text {. A } \\
\text { description and interpretation of the tests of this hypothesis are elaborated in the } \\
\text { paragraphs below. }\end{array}$ \\
\hline
\end{tabular}

The descriptive statistics for $\mathrm{H} 1$ are shown in Table 2. Approximately $39.5 \%$ of the sample use income-increasing CFO (DREM_CFO). The frequency for DREM_DISEXP is 54.9\%; for DREM_GOAS, it is $27.6 \%$; for $D D A$, it is $47 . \overline{7 \%}$. SUSPECT firm-year observations claim $19.3 \%$ of the sample. The percentages HOTEL and RESTAURANT industries are $0.5 \%$ (540 observations) and 2.4\% (2,595 observations), respectively. 
TABLE 2

DESCRIPTIVE STATISTICS (H1)

\begin{tabular}{|c|c|c|c|c|c|c|}
\hline Variable & $\mathrm{N}$ & Mean & Median & Std Dev & $\begin{array}{c}\text { Lower } \\
\text { Quartile }\end{array}$ & $\begin{array}{c}\text { Upper } \\
\text { Quartile }\end{array}$ \\
\hline DREM_CFO & 108,132 & 0.395 & 0.000 & 0.489 & 0.000 & 1.000 \\
\hline DREM_DISEXP & 108,132 & 0.549 & 1.000 & 0.498 & 0.000 & 1.000 \\
\hline DREM_GOAS & 108,132 & 0.276 & 0.000 & 0.447 & 0.000 & 1.000 \\
\hline$D D A$ & 108,132 & 0.477 & 0.000 & 0.499 & 0.000 & 1.000 \\
\hline SUSPECT & 108,132 & 0.193 & 0.000 & 0.395 & 0.000 & 1.000 \\
\hline HOTEL & 108,132 & 0.005 & 0.000 & 0.065 & 0.000 & 1.000 \\
\hline RESTAURANT & 108,132 & 0.024 & 0.000 & 0.141 & 0.000 & 1.000 \\
\hline SUSPECT ${ }^{*} H O T E L$ & 108,132 & 0.002 & 0.000 & 0.038 & 0.000 & 1.000 \\
\hline SUSPECT ${ }^{*} R E S T A U R A N T$ & 108,132 & 0.005 & 0.000 & 0.071 & 0.000 & 1.000 \\
\hline SIZE & 108,132 & 4.399 & 4.423 & 2.322 & 2.827 & 6.023 \\
\hline MTB & 108,132 & 0.240 & 0.065 & 6.362 & 0.017 & 0.198 \\
\hline$R O A$ & 108,132 & -0.286 & 0.020 & 4.664 & -0.109 & 0.081 \\
\hline
\end{tabular}

DREM_CFO = indicator variable set to 1 if abnormal cash flow from operations * $(-1)$ is greater than zero, otherwise, it is equal to zero

DREM_DISEXP $=\quad$ indicator variable set to 1 if abnormal discretionary expense * $(-1)$ is greater than zero; otherwise, it is equal to zero

$D R E M \_G O A S=$ indicator variable se to 1 if abnormal gain from asset sales * $(-1)$ is greater than zero; otherwise, it is equal to zero

DREM = indicator variable set to one if the sum of DREM_CFO, DREM_DISEXP, and DREM_GOAS is greater than zero; otherwise, it is equal to zero

SUSPECT $=$ indicator variable if $0.00=<$ zero earnings (net income/total assets at the beginning of the year) $<=0.01$, or $0.00=<$ earnings growth (change in net income/total assets at the beginning of the year) $<=0.01$; otherwise it is equal to zero

HOSPITALITY $=\quad$ indicator variable if two-digit SIC code is 58 (restaurant) or 70 (hotel); otherwise, it is zero

HOTEL = indicator variable if two-digit SIC code is 70; otherwise, it is equal to zero

RESTAURANT = indicator variable if two-digit SIC code is 58; otherwise, it is equal to zero

SIZE $\quad=\quad \log$ of assets

$M T B \quad$ = market to book ratio

ROA $=$ return on assets

Table 3 compares firms from other industries to HOTELs and RESTAURANTs. To ensure the robustness of the results, we apply non-parametric median score tests. HOTEL and RESTAURANT firms appear to apply REM_CFO and REM_GOAS to a larger extent than others, but apply REM_DISEXP and $D A$ to a much lesser extent than others. For instance, HOTEL firms apply more REM_CFO $(0.698)$ and REM_GOAS (0.688) compared to 0.499 from others. However, the magnitudes of REM_DISEXP $(0.276)$ and $\bar{D} A(0.418)$ are much smaller than those from others $(0.501)$ and $(0.500)$, significant at least at the 0.05 significant level, indicating that HOTELs and RESTAURANTs in general discretionarily expend more and do not use as much AEM as firms in other industries. The TQs for HOTEL and RESTAURANT are also significantly lower than that of others $(0.264$ vs. 0.501 for HOTEL, and 0.455 vs. 0.501 for RESTAURANT). 
TABLE 3

COMPARISON BETWEEN HOTELS/RESTAURANTS AND OTHERS

\begin{tabular}{lrrrrrrrr}
\hline & $(1)$ & $(3)$ & $(1)-(3)$ & $(2)$ & $(3)$ & $(2)-(3)$ \\
\hline & $H O T E L$ & Others & & & RESTAU \\
& RANT & Others & & \\
\hline REM_CFO & 0.698 & 0.499 & 0.199 & $* * *$ & 0.573 & 0.498 & 0.075 & $* * *$ \\
REM_DISEXP & 0.276 & 0.501 & -0.225 & $* * *$ & 0.447 & 0.501 & -0.054 & $* * *$ \\
REM_GOAS & 0.688 & 0.499 & 0.189 & $* * *$ & 0.543 & 0.499 & 0.044 & $* * *$ \\
DA & 0.418 & 0.500 & -0.082 & $* * *$ & 0.497 & 0.500 & -0.003 & \\
TQ & 0.264 & 0.501 & -0.237 & $* * *$ & 0.455 & 0.501 & -0.046 & $* * *$ \\
SIZE & 0.651 & 0.499 & 0.152 & $* * *$ & 0.481 & 0.500 & -0.019 & $* *$ \\
MTB & 0.466 & 0.500 & -0.034 & $*$ & 0.556 & 0.499 & 0.057 & $* * *$ \\
LEV & 0.780 & 0.499 & 0.281 & $* * *$ & 0.696 & 0.496 & 0.200 & $* * *$ \\
ROA & 0.418 & 0.500 & -0.082 & $* * *$ & 0.540 & 0.499 & 0.041 & $* * *$ \\
$Z$ SCORE & 0.206 & 0.501 & -0.295 & $* * *$ & 0.570 & 0.499 & 0.071 & $* * *$ \\
\hline \# of Obs. & 540 & 105,537 & & & 2,595 & 105,537 & & \\
\hline
\end{tabular}

Table 4 presents correlations among variables relevant to H1. While many correlations among variables are statistically significant, the magnitudes of them are not (very few of them are above 0.30 ), and the only few that are significant in magnitude are mechanical in nature. For example, the Pearson correlation between HOTEL and SUSPECT*HOTEL is 0.59 . 


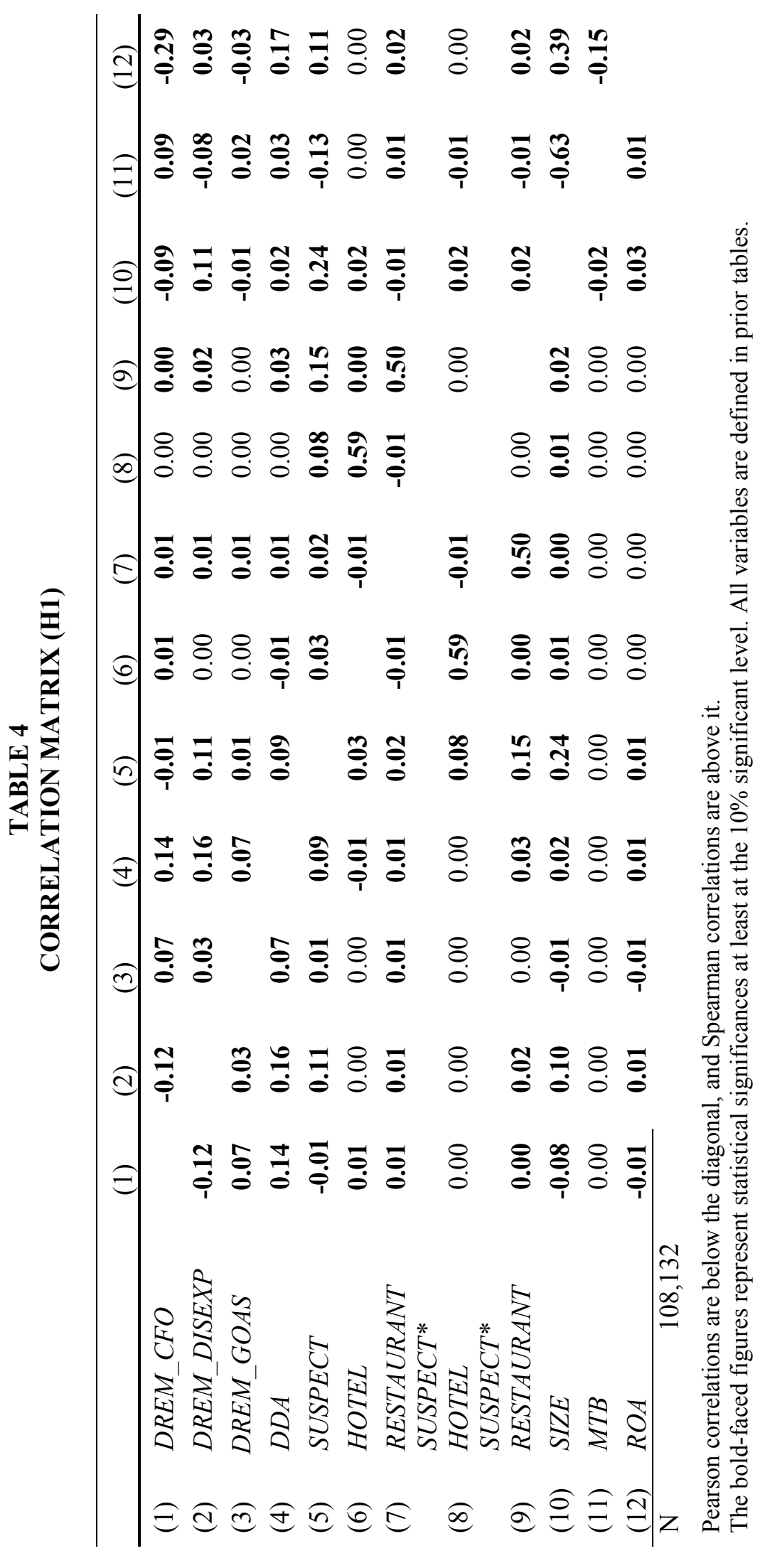


The correlations show that in general, SUSPECT is negatively associated with DREM_CFO, whereas it is positively correlated with DREM_DISEXP,DREM_GOAS, and DDA. HOTEL firms apply more $D R E M$ CFO and less DDA (coefficient -0.01), and HOTEL is not significantly correlated with either DREM_DISEXP or DREM_GOAS. However, RESTAURANT is positively and significantly correlated with all four earnings management measures, suggesting that RESTAURANTs tend to apply all four practices to boost earnings.

Interestingly, both HOTEL and RESTAURANT are positively and significantly correlated with $S U S P E C T$, indicating that firms in these two sectors of the hospitality industry more likely tend to meet/marginally exceed zero earnings/growth than firms in other industries. The coefficient between HOTEL and RESTAURANT is -0.01 and statistically significant, suggesting that these two industries demonstrate different characteristics. This relation manifests itself again in the correlation between RESTAURANT and the interaction term SUSPECT*HOTEL (coefficient -0.01). None of the four earnings management measures is significantly correlated with SUSPECT ${ }^{*} H O T E L$, whereas three out of four of them are positively and significantly correlated with SUSPECT*RESTAURANT, suggesting that in this study of the hospitality industry, RESTAURANTs dominate HOTELs in exhibiting earnings management behavior.

Table 5 presents the estimation results of Heckman (1979) Step One procedure. As expected, all variables exhibit predicted signs and statistical significances.

TABLE 5

HECKMAN (1979) STEP ONE ESTIMATION

\begin{tabular}{|c|c|c|c|c|c|}
\hline Paramater & Prediction & Estimate & Std. Error & Wald Chi-Sq & $\operatorname{Pr}>\mathrm{ChiSq}$ \\
\hline Intercept & & 1.3015 & 0.0142 & 8403.86 & $<.0001$ \\
\hline SHARES & + & 0.0103 & 0.0044 & 5.48 & 0.0193 \\
\hline$R O A_{t-1}$ & + & 0.0209 & 0.0031 & 44.67 & $<.0001$ \\
\hline$L E V_{t-1}$ & + & 0.0166 & 0.0056 & 8.84 & 0.0029 \\
\hline$S I C$ & & Yes & & & \\
\hline$Y E A R$ & & Yes & & & \\
\hline$N$ & & 108,132 & & & \\
\hline Likelihood & & Ratio & 148.72 & & \\
\hline$p$ value & & & $<.0001$ & & \\
\hline
\end{tabular}

SHARES are natural log of common shares outstanding; all other variables are defined in prior tables. 


\section{Extent of HOTEL/RESTAURANT Using Earnings Management to Meet/Marginally Beat Zero Earnings (Growth) - H1a through H1d}

Table 6 presents results for H1, demonstrating the extent to which and whether SUSPECT*HOTEL and SUSPECT*RESTAURANT apply earnings management to meet/marginally beat zero earnings/growth.

TABLE 6

RESULTS FOR TESTING H1-EXTENT OF SUSPECT * HOTEL/RESTAURANT USING EARNINGS MANAGEMENT

$$
\begin{aligned}
\text { DEM }_{t} / \mathrm{DDA}_{t} & =\eta_{0}+\eta_{1} \text { SUSPECT }_{t}+\eta_{2} \mathrm{HOTEL}_{t}+\eta_{3} \text { RESTAURANT } \eta_{4} \text { SUSPECT }^{*} \text { HOTEL }_{t} \\
& +\eta_{5} \text { SUSPECT }^{*} \text { RESTAURANT }_{t}+\eta_{6} \text { SIZE }_{t}+\eta_{7} \text { MTB }_{t}+\eta_{8} \text { ROA }_{t}+\eta_{9} \text { IMR }_{+} \varepsilon
\end{aligned}
$$

\begin{tabular}{|c|c|c|c|c|c|c|c|c|c|}
\hline \multirow[b]{2}{*}{ Intercept } & \multirow[b]{2}{*}{$\eta_{0}$} & \multicolumn{2}{|c|}{ DREM_CFO } & \multicolumn{2}{|c|}{ DREM_DISEXP } & \multicolumn{2}{|c|}{ DREM_GOAS } & \multicolumn{2}{|l|}{$D D A$} \\
\hline & & 10.1385 & $* * *$ & -11.4193 & $* * *$ & 5.5913 & $* * *$ & -14.6628 & $* * *$ \\
\hline SUSPECT & $\eta_{1}$ & 0.0845 & $* * *$ & -0.2804 & $* * *$ & -0.0077 & & -0.2758 & $* * *$ \\
\hline HOTEL & $\eta_{2}$ & -0.5914 & $* * *$ & 0.1402 & & -0.0494 & & 0.1938 & \\
\hline RESTAURANT & $\eta_{3}$ & -0.1426 & $* * *$ & -0.1978 & $* * *$ & -0.1608 & $* * *$ & 0.0518 & \\
\hline SUSPECT* HOTEL & $\eta_{4}$ & 0.2611 & & 0.2009 & & -0.1550 & & 0.3463 & $*$ \\
\hline SUSPECT ${ }^{*}$ RESTAURANT & $\eta_{5}$ & 0.2026 & $*$ & 0.1997 & * & 0.0181 & & -0.4297 & $* * *$ \\
\hline SIZE & $\eta_{6}$ & 0.1273 & $* * *$ & -0.0395 & $* * *$ & 0.0515 & $* * *$ & 0.0380 & $* * *$ \\
\hline$M T B$ & $\eta_{7}$ & -0.0001 & & 0.0002 & & 0.0002 & & -0.0002 & \\
\hline$R O A$ & $\eta_{8}$ & 0.0001 & $* * *$ & 0.0001 & & 0.0001 & & 0.0003 & $* * *$ \\
\hline$I M R$ & $\eta_{9}$ & -15.5414 & $* * *$ & 16.8269 & $* * *$ & -7.5880 & $* * *$ & 21.5837 & $* * *$ \\
\hline \# Obs. & & 108,132 & & 108,132 & & 108,132 & & 108,132 & \\
\hline Likelihood Ratio & & 2559.34 & & 970.76 & & 413.96 & & 834.55 & \\
\hline$p$-value & & $<.0001$ & $* * *$ & $<.0001$ & $* * *$ & $<.0001$ & $* * *$ & $<.0001$ & $* * *$ \\
\hline$F$-test $\eta_{4}+\eta_{5}$ & & 0.4637 & $* *$ & 0.4006 & $*$ & -0.1369 & & -0.0834 & \\
\hline Chi-Square & & 3.93 & & 2.93 & & 0.32 & & 0.13 & \\
\hline
\end{tabular}

$*, * *, * * *$ represent statistical significances at the $10 \%, 5 \%$, and $1 \%$ levels, respectively. All variables are defined previously.

The variables of interest are SUSPECT*HOTEL $\left(\eta_{4}\right)$ and SUSPECT*RESTAURANT $\left(\eta_{5}\right)$. SUSPECT*HOTEL is marginally positively significant when $D D A$ is the dependent variable, suggesting that HOTELs apply discretionary accruals to meet/marginally exceed zero earnings/growth. SUSPECT ${ }^{*} R E S T A U R A N T$ is positively associated with DREM_CFO (coefficient estimate 0.2026) and DREM_DISEXP (coefficient estimate 0.1997) although it is negatively associated with DDA (coefficient estimate -0.4297). These results suggest that even though hospitality firms are constrained with fixed capacity and seasonality issues and are labor-intensive, they, especially RESTAURANTs, are still able to offer deep discounts and/or lenient credit terms to promote sales (DREM_CFO) and cut down on discretionary expenses (DREM_DISEXP) to meet/marginally exceed earnings benchmarks. RESTAURANT dominates HOTEL in this process, supporting $\mathrm{H} 1 \mathrm{a}$ and $\mathrm{H} 1 \mathrm{~b}$. 
The coefficients of SUSPECT*HOTEL and SUSPECT*RESTAURANT are not significant when DREM_GOAS is the dependent variable, suggesting that HOTELS/RESTAURANTs are not different from other industries in applying GOAS to meet/marginally exceed zero earnings/growth, supporting H1c. SUSPECT*HOTEL is marginally positively associated with DDA (coefficient estimate 0.3463), suggesting that HOTELs tend to apply more discretionary accruals to meet/marginally exceed zero earnings/growth. However, SUSPECT*RESTAURANT is negatively associated with $D D A$ at a more significant level (coefficient estimate -0.4297), indicating that RESTAURANTs do not use as much discretionary accrual as firms in the other industries to meet/marginally exceed zero earnings/growth, supporting H1d.

Additional F-tests of coefficients SUSPECT*HOTEL and SUSPECT*RESTAURANT further support $\mathrm{H} 1 \mathrm{a}, \mathrm{H} 1 \mathrm{~b}$, and H1c. For example, the sum of $\eta 4$ and $\eta_{5}$ is 0.4637 when DREM_CFO is the dependent variable (significant at the 0.05 significance level), supporting H1a.

In summary, Table 6 shows that SUSPECT RESTAURANT dominates SUSPECT HOTEL in our sample in determining the combined effects of earnings management. Specifically, SUSPECT *RESTAURANT $\left(\eta_{5}\right)$ in Table 6 is significant and positive when the dependent variables are DREM_CFO and DREM_DISEXP, and the combined results from the $F$-tests still indicate significance and positivity. The results indicate that these firms offer deep discounts/lenient credit sales and/or cut discretionary expenses to meet/marginally exceed zero earnings/growth, and RESTAURANTs dominate HOTELs in these two respects. The results also suggest that SUSPECT ${ }^{*} H O T E L$ s do use income increasing discretionary accruals to meet/marginally exceed zero earnings/growth, whereas SUSPECT*RESTAURATNs do not use as much income-increasing discretionary accruals as firms in other industries. In addition, it seems that neither HOTELs nor RESTAURANTs resort to GOAS to meet/marginally beat zero earnings/growth.

\section{Market Valuation}

Descriptive statistics and correlations among the variables relevant to $\mathrm{H} 2$ are presented in Table 7 and Table 8. An inferential test of $\mathrm{H} 2$ is presented in Table 9. A description and an interpretation of the tests of this hypothesis are elaborated in the paragraphs below.

Table 7 depicts the descriptive statistics for variables relevant to $\mathrm{H} 2$. The mean of $T Q$ is 3.299 , indicating that the market value of an average firm is 3.299 times the book value. Approximately $61.7 \%$ of firms beat zero earnings/growth by more than $0.01,6.8 \%$ firms miss the benchmarks marginally, and $19.3 \%$ firms are SUSPECTs. 
TABLE 7

DESCRIPTIVE STATISTICS (H2)

\begin{tabular}{lcccrrr}
\hline Variable & $\mathrm{N}$ & Mean & Median & Std Dev & $\begin{array}{c}\text { Lower } \\
\text { Quartile }\end{array}$ & $\begin{array}{c}\text { Upper } \\
\text { Quartile }\end{array}$ \\
\hline$T Q$ & 105,691 & 3.299 & 1.230 & 9.361 & 0.810 & 2.175 \\
BEAT & 105,691 & 0.617 & 1.000 & 0.486 & 0.000 & 1.000 \\
JUSTMISS & 105,691 & 0.068 & 0.000 & 0.252 & 0.000 & 1.000 \\
SUSPECT & 105,691 & 0.193 & 0.000 & 0.395 & 0.000 & 1.000 \\
HOTEL & 105,691 & 0.004 & 0.000 & 0.065 & 0.000 & 1.000 \\
RESTAURANT & 105,691 & 0.020 & 0.000 & 0.141 & 0.000 & 1.000 \\
DREM_CFO & 105,691 & 0.395 & 0.000 & 0.489 & 0.000 & 1.000 \\
DREM_DISEXP & 105,691 & 0.549 & 1.000 & 0.498 & 0.000 & 1.000 \\
DREM_GOAS & 105,691 & 0.276 & 0.000 & 0.447 & 0.000 & 1.000 \\
DDA & 105,691 & 0.477 & 0.000 & 0.499 & 0.000 & 1.000 \\
SIZE & 105,691 & 4.399 & 4.423 & 2.322 & 2.827 & 6.023 \\
MTB & 105,691 & 0.240 & 0.065 & 5.632 & 0.017 & 0.198 \\
LEV & 105,691 & 0.920 & 0.094 & 8.219 & 0.000 & 0.296 \\
$Z$ ZSCORE & 105,691 & -3.256 & 1.615 & 4.824 & -0.207 & 2.866 \\
\hline BEAT is a & & & & \\
\hline
\end{tabular}

$B E A T$ is an indicator variable set to 1 if zero earnings $>0.01$ or earnings growth $>0.01$; otherwise, it is equal to zero; JUSTMISS is an indicator variable set to 1 if $-0.01=<$ zero earnings $<0.00$, or $-0.01=<$ earnings growth $=<$ 0.00 ; otherwise, it is equal to zero; Other variables are defined in prior tables.

Table 8 shows correlations among variables relevant to $\mathrm{H} 2$. While many correlations are statistically significant, the magnitudes are not (very few of them are above 0.30 ). The Spearman correlation between $M T B$ and SIZE is -0.63 , indicating that large firms are not growth firms. SIZE is also positively associated with $L E V$ (Spearman $\mathrm{r}$ is 0.33), suggesting large firms use more long-term debt in their capital structure. Large firms and leveraged firms are also financially healthier, since the Spearman correlation is 0.39 and the Pearson correlation is 0.53 . In addition, $B E A T$ is positively correlated with $Z$ _SCORE, suggesting that healthier firms tend to $B E A T$ zero earnings/growth.

The domination of RESTAURANT over HOTEL is also shown in Table 8. HOTEL is only positively correlated with DREM_CFO (coefficient 0.01 ), whereas RESTAURANT is positively and significantly correlated with all three $R E M$ measures. 


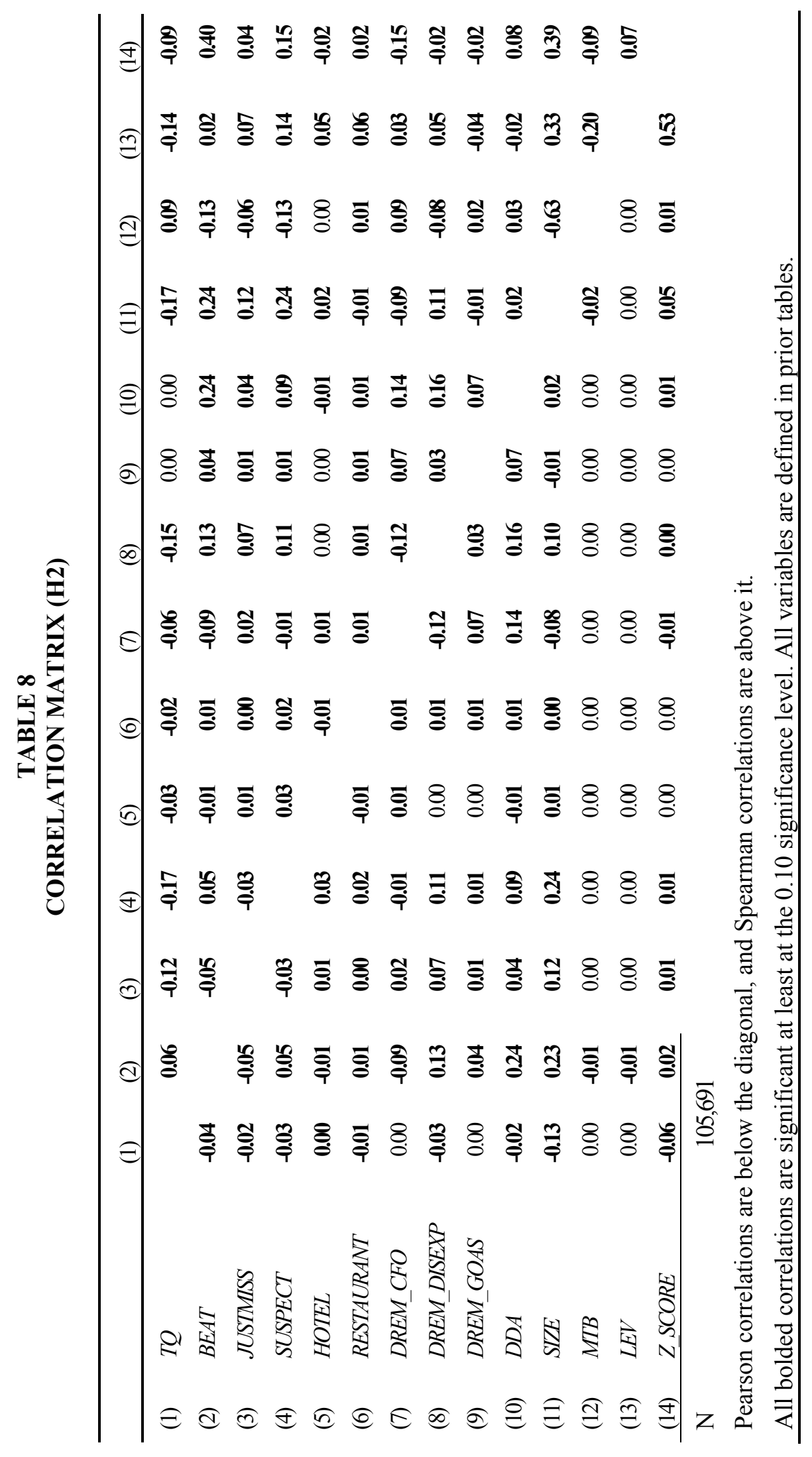




\section{Market Valuation of SUSPECT*HOTEL/RESTAURANT Using Earnings Management - H2}

Table 9 exhibits the market valuation of SUSPECT ${ }^{*} H O T E L / R E S T A U R A N T$ firms when they apply $D R E M$ or $D D A$ to meet/marginally exceed zero earnings/growth. The results for variables of interest are bold-faced in Table 9. The positivity and significance of the interaction terms indicate that the market rewards these firms, especially SUSPECT*HOTEL firms, if they use earnings management to meet/marginally exceed earnings benchmarks.

For instance, the coefficient estimate of SUSPECT*HOTEL*DREM_CFO is positive (1.3590), and it

is statistically significant at 0.05 significance level. The coefficient estimate of SUSPECT*RESTAURANT*DREM_CFO is positive (0.3912). However, it is not statistically significant. The same pattern continues when we examine the other three columns in which we test the market valuation when SUSPECT*HOTEL firms use DREM_DISEXP,DREM_GOAS, and DDA. For example, the coefficient estimate of SUSPECT*HOTEL*DREM_GOAS is 1.4059 , significant at 0.05 significance level; the corresponding estimate for RESTAURANT is positive (0.4258) but not statistically significant.

The signs of other variable estimates are general as predicted. For instance, the coefficient estimates for BEAT are all positive and statistically significant. Interestingly, HOTEL and RESTAURANT firms, especially RESTAURANT firms are not valued highly by the equity market. For example, the coefficient estimate for REESTAURANT is -0.9641 when DREM_CFO is used as the REM measure. The signs for two $D R E M / D D A$ measures are negative and statistically significant, exhibiting their value-destroying nature. Coefficient estimates of SIZE and $L E V$ are all negative and statistically significant as predicted. However, the coefficient estimates for MTB and $Z$ SCORE are not statistically significant.

In summary, the results presented in Table 9 suggest that the market rewards SUSPECT hospitality firms, especially SUSPECT*HOTEL firms if they apply DREM_CFO,DREM_DISEXP,DREM_GOAS, and $D D A$ to meet/marginally exceed zero earnings/growth.

Even though the Heckman (1979) Two-Step procedure addresses the self-selection bias issue related to SUSPECT, it still makes sense to further control for the endogeneity problem caused by omitted variables in the valuation test. Wooldridge $(2009$, p. 310) suggests using lagged dependent variable to mitigate the omitted variable problem when proxy variables are difficult to identify. Therefore, we perform the valuation test by adding $T Q_{t-1}$ as an additional control variable to control for problems caused by any omitted variables that are correlated with SUSPECT and any DREM/DDA measures. The results for this test are shown in Table 10. 


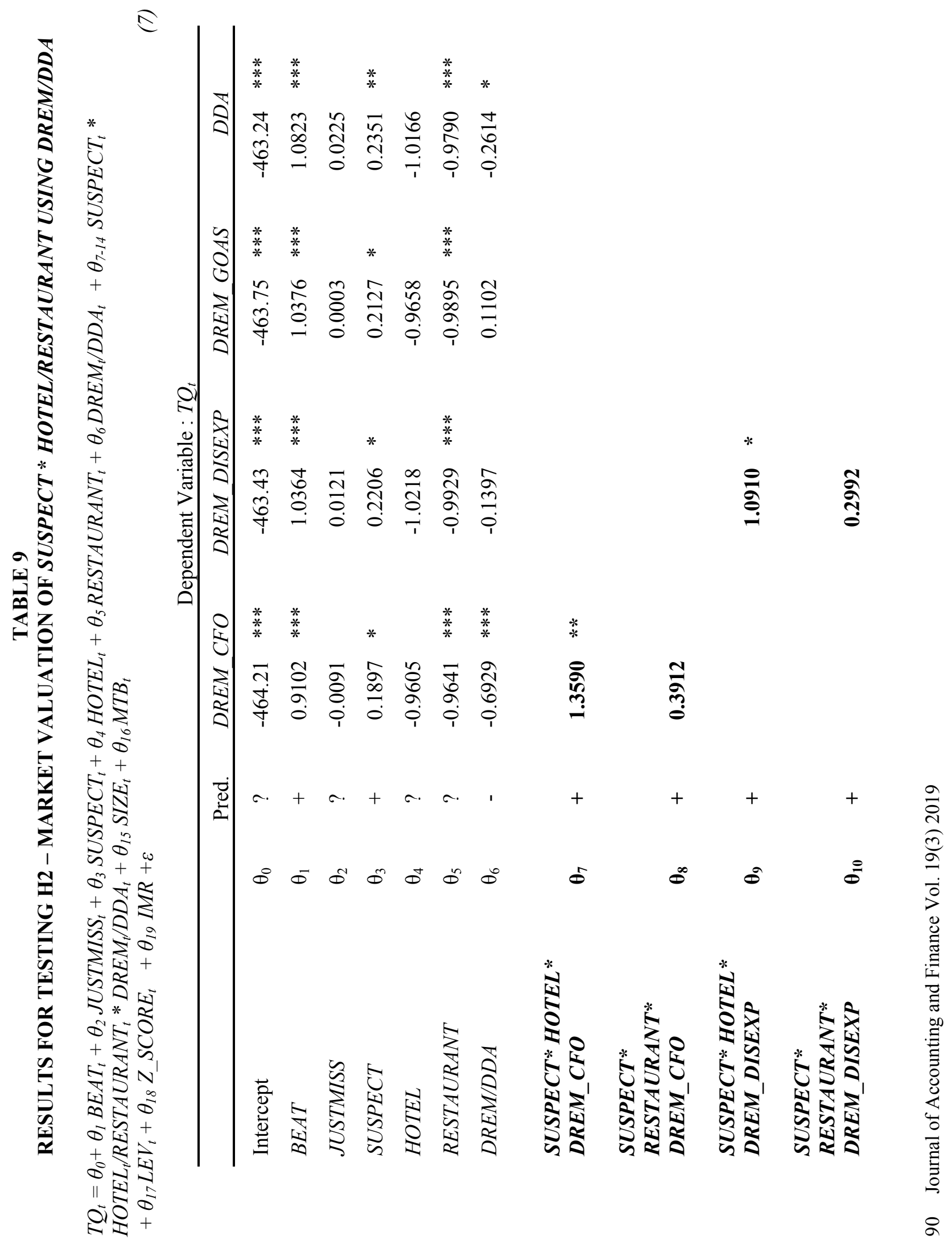




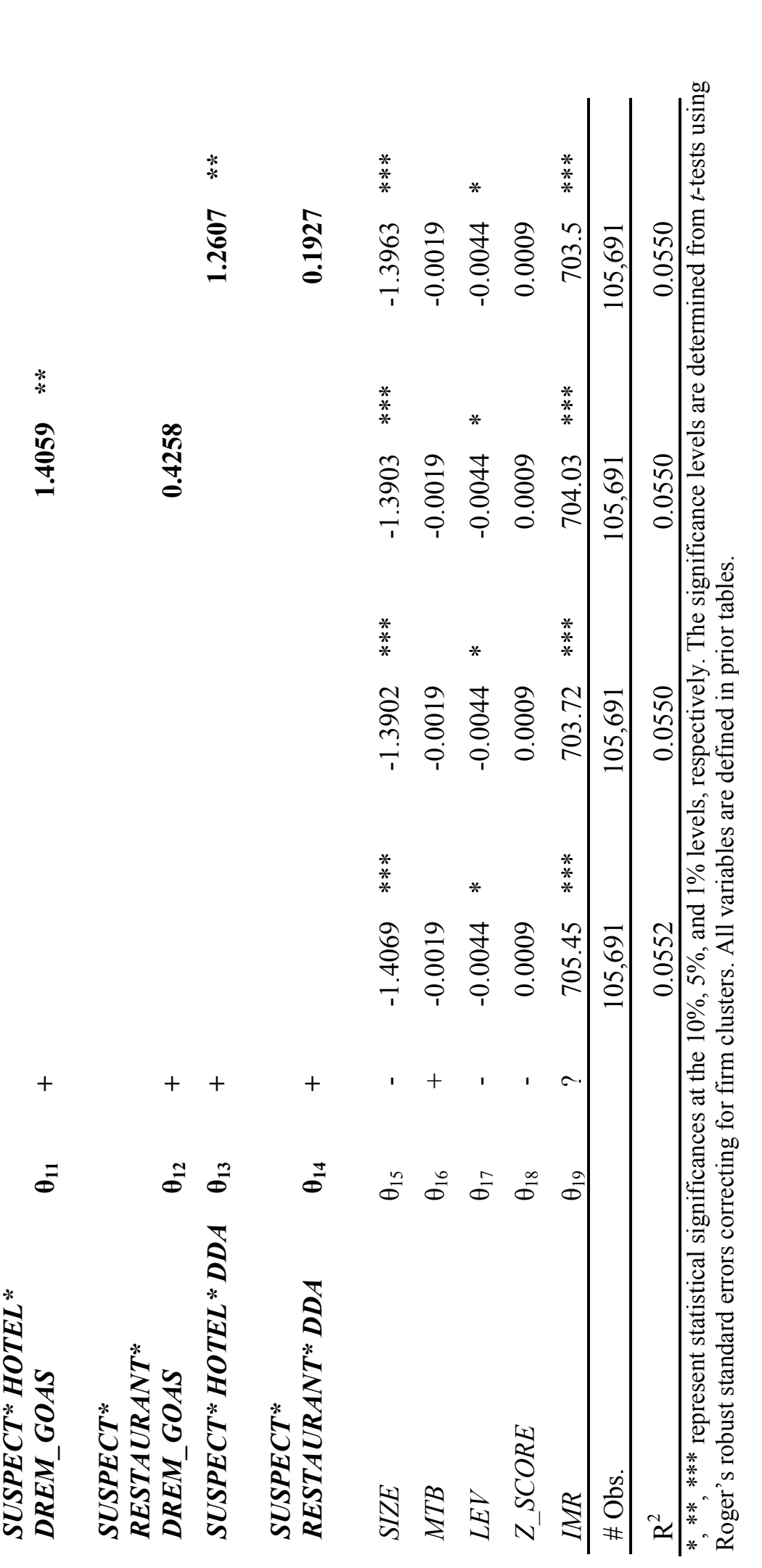


TABLE 10

RESULTS FOR TESTING H2 - OMITTED VARIABLE PROBLEM MITIGATION

$T Q_{t}=\theta_{0}+\theta_{1} T Q_{t-1}+\theta_{2}$ BEAT $_{t}+\theta_{3}$ JUSTMISS $_{t}+\theta_{4}$ SUSPECT $_{t}+\theta_{5}$ HOTEL $_{t}+\theta_{6}$ RESTAURANT $_{t}+\theta_{7}$ DREM $_{t} / D D A_{t}+\theta_{8-15}$ SUSPECT $_{t} *$ HOTEL $_{t} /$ RESTAURANT $_{t} * \mathrm{DREM}_{t} / D D A_{t}+\theta_{16} \mathrm{SIZE}_{t}+\theta_{17} M_{1} B_{t}+\theta_{18}$ $L E V_{t}+\theta_{19} Z S_{S C O R E_{t}}+\theta_{20} I M R+\varepsilon$

Dependent Variable : $T Q_{t}$

\begin{tabular}{|c|c|c|c|c|c|c|c|c|c|}
\hline \multirow[b]{2}{*}{ Intercept } & \multirow[b]{2}{*}{$\theta_{0}$} & \multicolumn{2}{|c|}{ DREM_CFO } & \multicolumn{2}{|c|}{ DREM_DISEXP } & \multicolumn{2}{|c|}{ DREM_GOAS } & \multicolumn{2}{|c|}{$D D A$} \\
\hline & & -348.17 & $* * *$ & -347.70 & $* * *$ & -347.77 & $* * *$ & -347.46 & $* * *$ \\
\hline$T Q_{t-1}$ & $\theta_{1}$ & 0.2061 & $* * *$ & 0.2061 & $* * *$ & 0.2061 & $* * *$ & 0.2061 & $* * *$ \\
\hline$B E A T$ & $\theta_{2}$ & 0.7366 & $* * *$ & 0.8141 & $* * *$ & 0.8198 & $* * *$ & 0.8489 & $* * *$ \\
\hline JUSTMISS & $\theta_{3}$ & 0.0173 & & 0.0276 & & 0.0203 & & 0.0382 & \\
\hline SUSPECT & $\theta_{4}$ & 0.1915 & $* *$ & 0.2082 & $* *$ & 0.2066 & $* *$ & 0.2220 & $* *$ \\
\hline HOTEL & $\theta_{5}$ & -0.8265 & & -0.8860 & & -0.8188 & & -0.8789 & \\
\hline RESTAURANT & $\theta_{6}$ & -0.7468 & $* * *$ & -0.7763 & $* * *$ & -0.7643 & $* * *$ & -0.7603 & $* * *$ \\
\hline$D R E M / D D A$ & $\theta_{7}$ & -0.4473 & $* * *$ & -0.0781 & & 0.2803 & $* *$ & -0.1973 & $* *$ \\
\hline $\begin{array}{l}\text { SUSPECT* } \\
\text { HOTEL * } \\
\text { DREM_CFO }\end{array}$ & $\theta_{8}$ & 1.0238 & $*$ & & & & & & \\
\hline $\begin{array}{l}\text { SUSPECT* } \\
\text { RESTAURANT* } \\
\text { DREM_CFO }\end{array}$ & $\theta_{9}$ & 0.2464 & & & & & & & \\
\hline $\begin{array}{l}\text { SUSPECT* } \\
\text { HOTEL * } \\
\text { DREM_DISEXP }\end{array}$ & $\theta_{10}$ & & & 0.9262 & & & & & \\
\hline $\begin{array}{l}\text { SUSPECT* } \\
\text { RESTAURANT* } \\
\text { DREM_DISEXP }\end{array}$ & $\theta_{11}$ & & & 0.2401 & & & & & \\
\hline $\begin{array}{l}\text { SUSPECT* } \\
\text { HOTEL* } \\
\text { DREM_GOAS }\end{array}$ & $\theta_{12}$ & & & & & 1.0039 & $*$ & & \\
\hline $\begin{array}{l}\text { SUSPECT* } \\
\text { RESTAURANT* } \\
\text { DREM_GOAS }\end{array}$ & $\theta_{13}$ & & & & & 0.2097 & & & \\
\hline $\begin{array}{l}\text { SUSPECT* } \\
\text { HOTEL * DDA }\end{array}$ & $\theta_{14}$ & & & & & & & 1.0902 & $* *$ \\
\hline $\begin{array}{l}\text { SUSPECT* } \\
R E S T A U R A N T^{*} \\
D D A\end{array}$ & $\theta_{15}$ & & & & & & & 0.1430 & \\
\hline
\end{tabular}

92 Journal of Accounting and Finance Vol. 19(3) 2019 


\begin{tabular}{|c|c|c|c|c|c|c|c|c|c|}
\hline SIZE & $\theta_{16}$ & -1.0661 & $* * *$ & -1.0554 & $* * *$ & -1.0532 & $* * *$ & -1.0596 & $* * *$ \\
\hline$M T B$ & $\theta_{17}$ & -0.0042 & & -0.0042 & & -0.0042 & & -0.0042 & \\
\hline$L E V$ & $\theta_{18}$ & -0.0017 & & -0.0017 & & -0.0017 & & -0.0017 & \\
\hline Z_SCORE & $\theta_{19}$ & -0.0002 & & -0.0002 & & -0.0002 & & -0.0002 & \\
\hline$I M R$ & $\theta_{20}$ & 529.09 & $* * *$ & 528.02 & $* * *$ & 527.90 & $* * *$ & 527.73 & $* * *$ \\
\hline \# Obs. & & 99,017 & & 99,017 & & 99,017 & & 99,017 & \\
\hline $\mathrm{R}^{2}$ & & 0.1254 & & 0.1253 & & 0.1253 & & 0.1253 & \\
\hline
\end{tabular}

Results of Table 10 generally support the findings of Table 9. The coefficients of variables of interest are still positive and statistically significant for SUSPECT*HOTEL*DREM_CFO and SUSPECT*HOTEL*DDA. The only difference between the findings of Table 9 and Table 10 is one level weaker of the significance level. In Table 10, the coefficient estimate of SUSPECT*HOTEL*GOAS, not that of SUSPECT*HOTEL*DREM_DISEXP, is statistically significant (1.0039, significant at 0.10 significance level). The coefficient estimate of $\mathrm{TQ}_{\mathrm{t}-1}$ is positive and statistically significant at 0.01 significance level, suggesting time-series nature of valuation. The signs of other variables are generally similar to those in Table 9. In sum, after controlling for omitted-variable problems, valuation results still corroborate the signaling effect of earnings management that firms use to meet/marginally beat zero earnings/growth.

\section{CONCLUSIONS}

Hotels and restaurants in the hospitality industry have experienced unprecedented growth in recent decades. Using a large set of data of public firms, we hypothesize and find that hotels and restaurants that meet/marginally exceed zero earnings/growth are able to offer deep discounts, and/or lenient credit terms to promote sales in slow seasons. Hotel and restaurant managers are able to reduce discretionary expenses to increase earnings; and hotels, but not restaurants that meet/marginally exceed zero earnings/growth are able to apply income-increasing discretionary accruals to avoid a negative market valuation. Further, restaurants dominate hotels in demonstrating certain earnings management behaviors of meeting/marginally exceeding zero earnings/growth. If hospitality firms apply these earnings management practices to achieve the expected reporting thresholds, the market rewards these firms with a significant premium.

These findings intuitively reflect the characteristics of the hospitality industry. The chief output of this industry is service, which is intangible and perishable in nature. The constrained capacity in its inventory of hotel rooms or restaurant tables and the seasonal nature of the business provide both challenges and opportunities for hotel and restaurant managers. In this respect, hospitality managers are still able to promote sales in slow seasons by offering deep discounts, and/or lenient credit terms. The labor-intensive nature of this industry dictates high labor costs. However, hospitality managers can implement effective HR management policies so that they can reduce the labor costs to achieve the expected reporting thresholds. In addition, the relative intensity of depreciable fixed assets of hotels provides hotel managers with an opportunity to manage discretionary accruals to achieve the expected earnings thresholds. However, the relative scarcity in salable fixed assets in both hotels and restaurants do not provide much room for these managers to manage asset sales as an expediency of earnings management. 
These findings have important practical implications for managers of public hospitality firms. The market rewards those hospitality firms that use earnings management to meet/marginally exceed zero earnings/growth, and managers of these firms should strive to achieve the expected goals. In the first place, hospitality managers should prioritize service quality. The seasonal nature of this industry makes it even more important so that hotels/restaurants can have repeated business from value-added customers who are service quality oriented but not price sensitive. This business strategy should allow hospitality managers to effectively and efficiently manage cash flow from operations to meet/marginally beat earnings benchmarks.

In the second place, the labor-intensive nature of the hospitality industry calls for effective HR management so that hotel/restaurant managers can achieve earnings benchmarks by reducing costs related to employee training and career development without jeopardizing the service quality. Kusluvan et al (2010) summarize articles related to HR management and conclude that existing exemplary HR practices only occur in a few "large, foreign-owned, international chain establishments." This implies an area where great potential exists for hospitality managers to reduce labor costs so that they can meet/marginally beat earnings benchmarks.

In the third place, different from restaurants, hotels are intensive in depreciable fixed assets, providing managers with an opportunity to manage discretionary accruals, if necessary, to meet/marginally exceed expected reporting goals. However, due to the reversal nature of total accruals (Matsumoto 2002) and the strict scrutiny placed by the independent auditors and regulators (Brown and Pinello, 2007) managers should apply this practice with caution.

In the fourth place, it seems that both hotels and restaurants are constrained in their capabilities to apply gain on asset sales as an earnings management practice. However, since selling fixed assets is not the main stream of the business, the infeasibility of this earnings management practice does not really mean much to hospitality managers. From another perspective, it may indicate that hospitality managers are actually effective and efficient in managing fixed assets.

Finally, it seems clear that the equity market rewards hospitality managers who apply earnings management to meet/marginally beat earnings benchmarks. Even though hospitality managers have their own global industry goals, such as the Smith Travel Accommodations Report (STAR) benchmarks, managers from public hospitality firms are not different from managers in other industries, and they are similarly sensitive to what the equity market values them.

The study makes clear contributions. It also has some limitations which are avenues for future research. First, our hospitality industry covers only hotels and restaurants. Generalizability of our empirical results may be subject to limitations to other areas of the hospitality industry, such as airlines, theme parks, and casino establishments. Second, we mitigate the endogeneity problem in regressions by using Heckman (1979) Two-Step procedure and the lagged dependent variable. However, this does not exclude other threats that may still cause the results to be inconsistent and biased. 


\section{REFERENCES}

Altman, E. I. (1968). Financial ratios, discriminant analysis and the prediction of corporate bankruptcy. The Journal of Finance, 23(4), 589-609.

Anderson, R. C., \& Reeb, D. M. (2003). Founding-family ownership and firm performance: evidence from the S\&P 500. The Journal of Finance, 58-3, 1301-1328.

Bartov, E. (1993). The timing of asset sales and earnings manipulation. The Accounting Review, 840-855.

Bartov, E., Givoly, D., \& Hayn, C. (2002). The rewards to meeting or beating earnings expectations. Journal of Accounting and Economics, 33, 173-204.

Bhojraj, S., Hribar, P., Picconi, M., \& McInnis, J. (2009). Making sense of cents: An examination of firms that marginally miss or beat analyst forecasts. The Journal of Finance, 64(5), 2361-2388.

Brown, L. D. (2001). A temporal analysis of earnings surprises: Profits versus losses. Journal of Accounting Research, 39(2), 221-241.

Brown, L.D., \& Caylor, M. L. (2005). A temporal analysis of quarterly earnings thresholds: Propensities and valuation consequences. The Accounting Review, 80(2), 423-440.

Brown, L. D., \& Pinello, A. S. (2007). To what extent does the financial reporting process curb earnings surprise games?. Journal of Accounting Research, 45(5), 947-981.

Burgstahler, D., \& Dichev, I. (1997). Earnings management to avoid earnings decreases and losses. Journal of Accounting and Economics, 24, 99-126.

Chen, M., \& Kim, W. G. (2010). Hotel valuation in China: A case study of a state-owned hotel. Cornell Hospitality Quarterly, 429-445.

Degeorge, F., Patel, J., \& Zeckhauser, R. (1999). Earnings management to exceed thresholds. Journal of Business, 72(1), 1-33.

Eldenburg, L. G., Gunny, K. A., Hee, K. W., \& Soderstrom, N. (2011). Earnings management using real activities: Evidence from nonprofit hospitals. The Accounting Review, 86(5), 1605-1630.

Givoly, D., \& Ronen, J. (1981). 'Smoothing' manifestations in fourth quarter results of operations: Some empirical evidence. Abacus, 17(2), 174-193.

Graham, J. R., Harvey, C. R., \& Rajgopal, S. (2005). The economic implications of corporate financial reporting. Journal of Accounting and Economics, 40, 3-73.

Gunny, K. A. (2005). What are the consequences of real earnings management? W4.stern.nyu.edu. Retrieved from http://citeseerx.ist.psu.edu/viewdoc/download?doi=10.1.1.463.841\&rep=rep1\&type=pdf on December 2018.

Gunny, K. A. (2010). The relation between earnings management using real activities manipulation and future performance: Evidence from meeting earnings benchmarks. Contemporary Accounting Research, 27, (3), 855-888.

Healy, P. M. (1985). The effect of bonus schemes on accounting decisions. Journal of Accounting and Economics, 7, 85-107.

Healy, P. M., \& Wahlen, J. M. (1999). A review of the earnings management literature and its implications for standard setting. Accounting Horizons, 13(4), 365-383.

Heckman, J. J. (1979). Sample selection bias as a specification error. Econometrica, 47(1), 153-161.

Hesford, J. W., \& Potter, G. (2010). Accounting research in the Cornell Quarterly: A review with suggestions for future research. Cornell Hospitality Quarterly, 51(4), 502-512.

Jiang, J. (2008). Beating earnings benchmarks and the cost of debt. The Accounting Review, 83(2), 377416.

Jolliffe, L., \& Farnsworth, R. (2003). Seasonality in tourism employment: Human resource challenges. International Journal of Contemporary Hospitality Management 15(6), 312-316.

Jones, J. J. (1991). Earnings management during import relief investigations. Journal of Accounting Research, 29, 193-228.

Juarez, F. (2014). Fixed assets-infrastructure and financial health in hospitality industry: A chaotic effect in emerging markets. Wseas Transactions on Business and Economics, 11, 488-498. 
Kaplan, S. N., \& Zingales, L. (1997). Do investment-cash flow sensitivities provide useful measures of financing constraints? The Quarterly Journal of Economics, 112(1), 169-215.

Kothari, S. P., Leone, A. J., \& Wasley, C. E. (2005). Performance matched discretionary accrual measures. Journal of Accounting and Economics, 39, 163-197.

Kusluvan, S., Kusluvan, Z., Ilhan, I., \& Byuruk, L. (2010). A review of human resources management issues in the tourism and hospitality industry. Cornell Hospitality Quarterly, 51(2), 171-214.

Law, R., Leung, D., \& Cheung, C. (2012). A systematic review, analysis, and evaluation of research articles in the Cornell Hospitality Quarterly. Cornell Hospitality Quarterly, 365-381.

Matsumoto, D. A. (2002). Management's incentives to avoid negative earnings surprises. The Accounting Review, 77(3), 483-514.

Pincus, M., \& Rajgopal, S. (2002). The interaction between accrual management and hedging: Evidence from oil and gas firms. The Accounting Review, 77, (1), 127-160.

Roychowdhury, S. (2006). Earnings management through real activities manipulation. Journal of Accounting and Economics, 42, 335-370.

Schmenner, R. W. (1986). How can service business survive and prosper? Sloan Management Review, 27, (3), 21-32.

Skinner, D. J., \& Sloan, R. G. (2002). Earnings surprises, growth expectations, and stock returns. Review of Accounting Studies, 7, 289-312.

Song, Z., Chon, K., Ding, G., \& Gu, C. (2015). Impact of organizational socialization tactics on newcomer job satisfaction and engagement: Core self-evaluations as moderators. International Journal of Hospitality Management, 46, 180-189.

Trueman, B., \& Titman, S. (1988). An explanation for accounting income smoothing. Journal of Accounting Research, 26, 127-139.

Wooldridge, J. M. (2009). Introductory Econometrics: A Modern Approach, Mason, OH: South-Western Cengage Learning.

World Economic Forum (2018). Why China will soon be the world's top destination for tourists? Retrieved from https://www.weforum.org/agenda/2018/11/china-will-be-the-world-s-top-touristdestination-by-2030/_in December 2018.

Yoo, M., Lee, S., \& Bai, B. (2011). Hospitality marketing research from 2000 to 2009: topics, methods, and trends. International Journal of Contemporary Hospitality Management, 23-4, 517-532.

Zang, A. (2012). Evidence on the trade-off between real activities manipulation and accrual-based earnings management. The Accounting Review, 87(2), 675-703. 